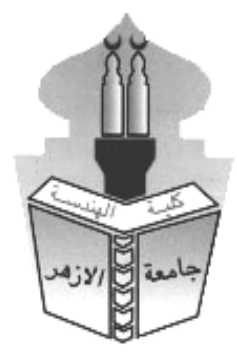

\title{
TOWARDS OPTIMUM UTILIZATION OF THE GROUND SURFACES BLOW THE BRIDGES
}

\author{
Emad Osman Moustafa \\ Urban Planning Department, Faculty of Engineering, Al-Azhar University, Egypt \\ E-mail: Dr_emadosman@azhar.edu.eg
}

\begin{abstract}
Although overhead bridges mainly work to achieve horizontal contact between separate areas as a result of crossing waterways or railways, or used to facilitate traffic. However, it causes the emergence of some urban problems in the areas that transit through it by turning the surfaces below those bridges into dark and deserted areas where waste accumulates and garbage is dumped and even at night it becomes a shelter for criminals.

Hence, the aim of the research is not the purely urban exploitation of those spaces, but the broader goal of the study is to achieve a set of integrated goals related to the various social, economic and environmental sectors resulting from urban development processes.

Where the social goals are to create urban spaces that accommodate the social activities of the population, which are difficult to provide in urban gatherings adjacent to these sites due to the lack of available space surfaces.

As for the economic goals, they are to provide commercial activities and small and micro projects. Which provide the necessary services for pedestrians in transit or for residents residing on either side of those sites that will become these foci Active attraction to them.

As for the environmental goals, it is to transform those sites, to areas controlled by green and open spaces, which help with other sites grown in the same way in providing a connected network of public spaces that serve as an outlet for the residents and lung of the surrounding urban areas characterized by overcrowding, urban concentration and traffic congestion.
\end{abstract}

\section{KEYWORDS: Bridges, Commercial Activities, Small Projects, Micro Project, Versatility.}

$$
\text { قحو استغلال أمثل للمسطحات الأرضية أسفل الكباري العلوية }
$$

البريد الاليكتروني للباحث: E-mail: Dr_emadosman@azhar.edu.eg ،

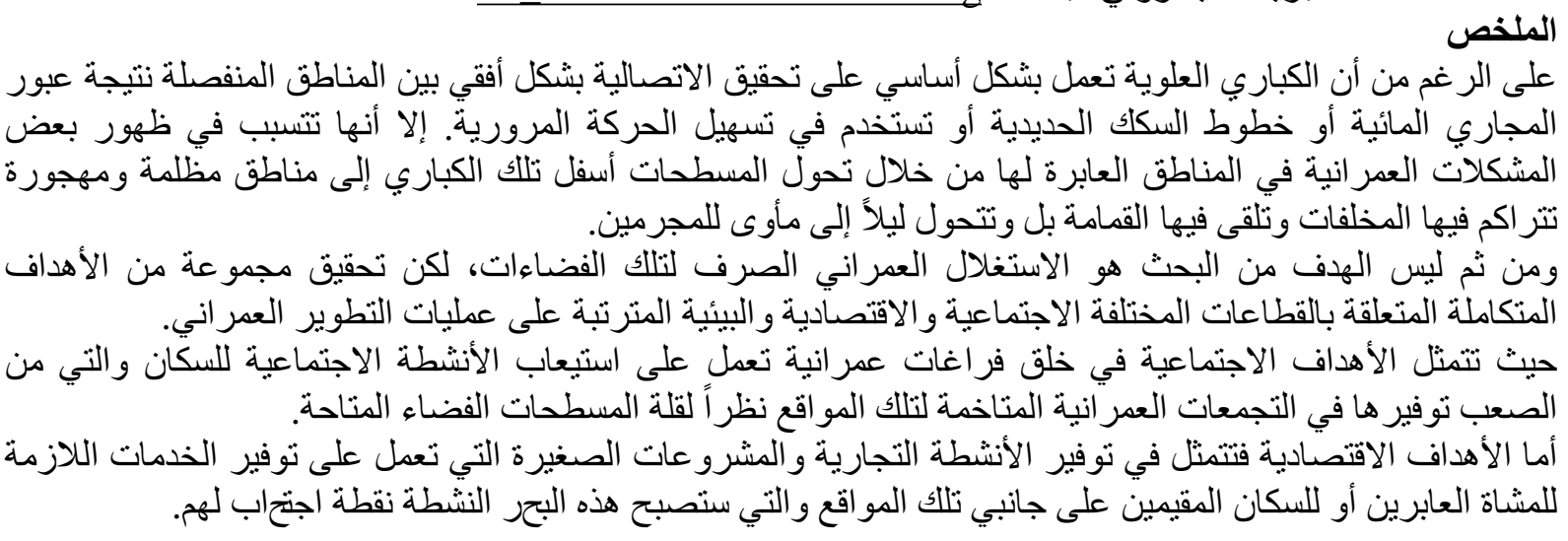




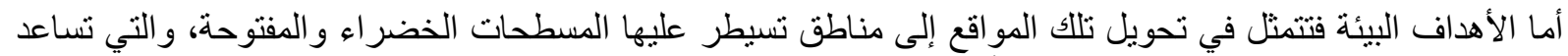

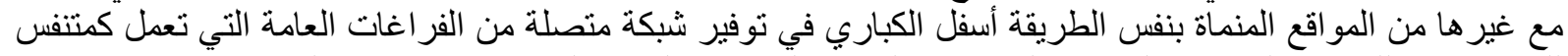

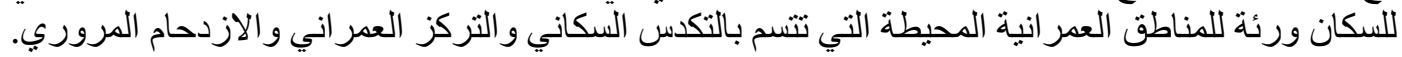

الكلمات المفتاحية: الكباري، الأنشطة التجارية، المشروع الصغير، المشروع متناهي الصغر، تعدد الاستخذامات.

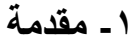

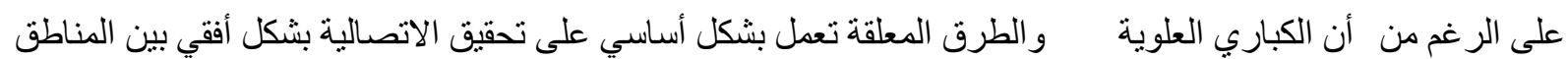

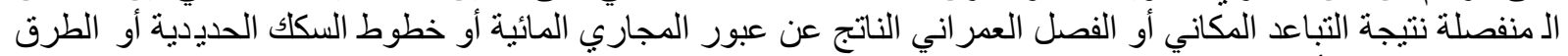

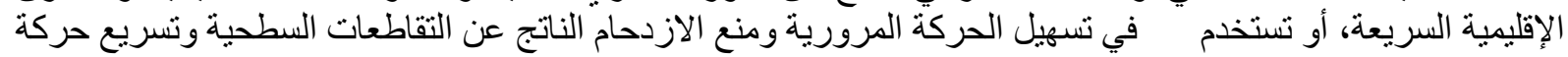

إلا أنها تتسبب في ظهور بعض الم شكلات العمر انية في المناطق التي تعبر من خلالها، وذللك من خلال تحول تلإل الك الكباري

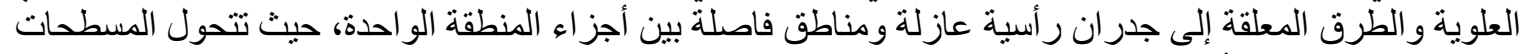

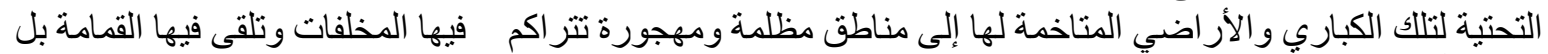

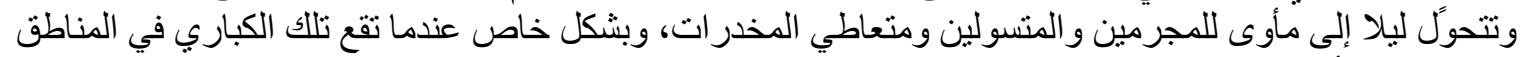

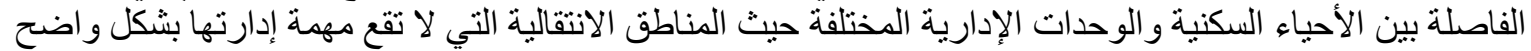

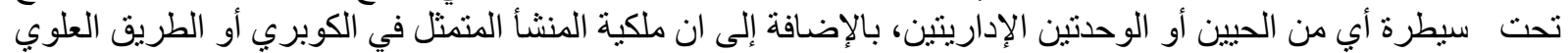

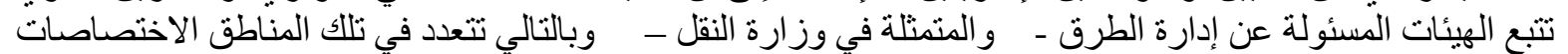

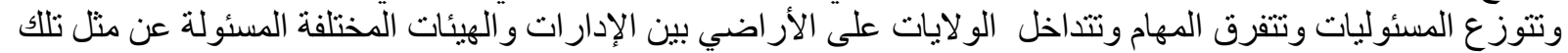

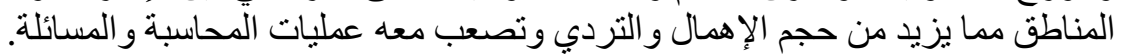
ا ـ أسباب اختيار البحث.

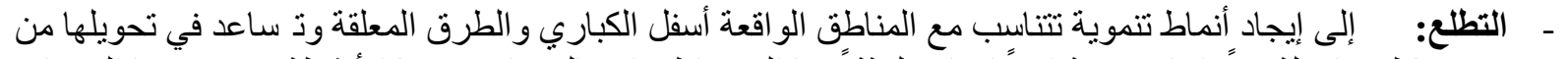

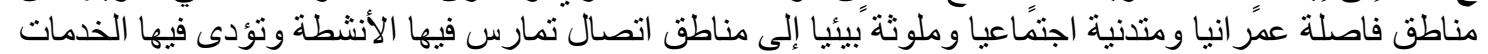

$$
\text { ويقيم فيها السكان. }
$$

- الاستفادة: من الأر اضي غير المستغلة الواقعة تحت الكباري و الطرق المعلقة والتي تصل مسطحاتها إلى آلاف الأفدنة

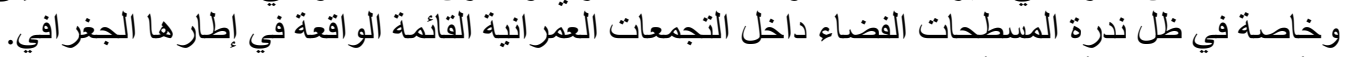

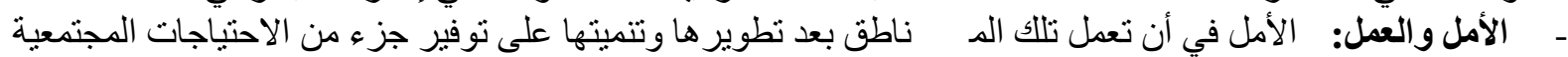

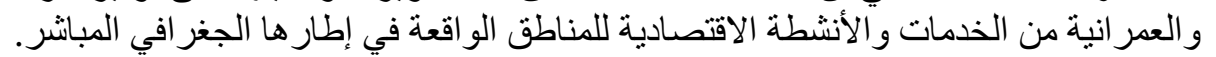

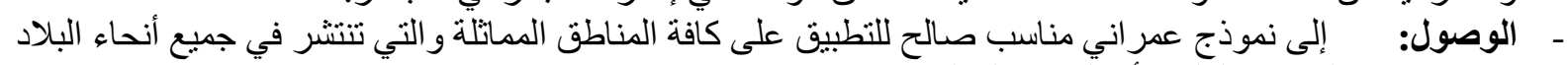
حيثما وجدت الكباري العلوية أو الطرق الطرق المعلقة.

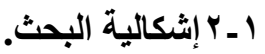

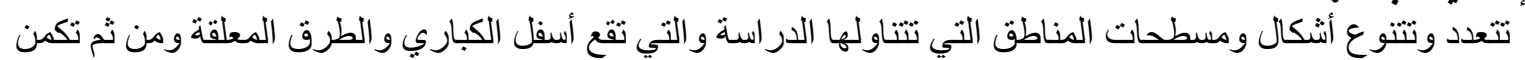

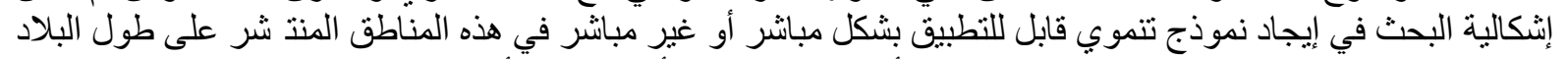

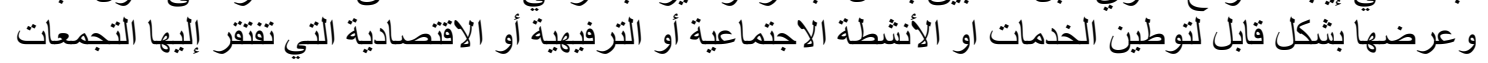

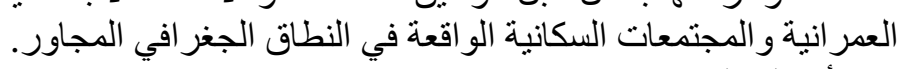

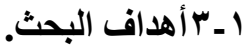

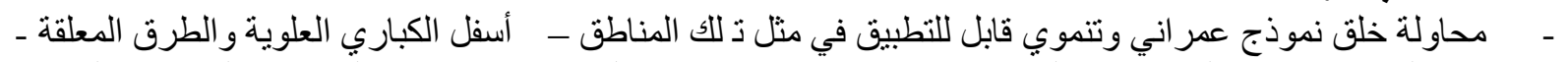

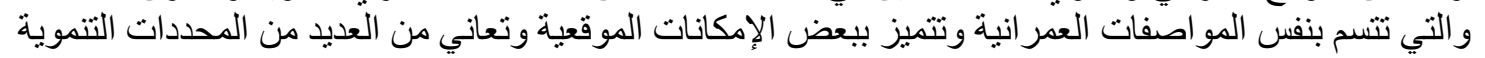
وتتوددها ألكثير من المخاطر البيئية و الاجتماعية.

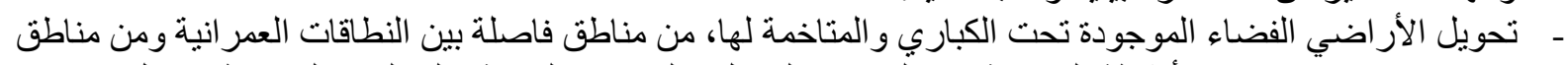

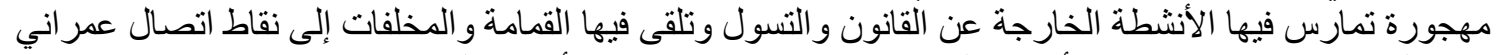

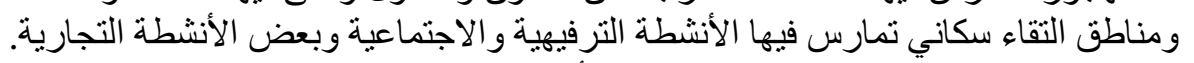

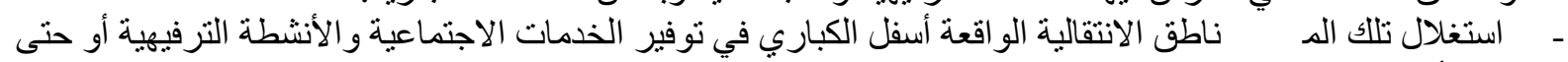

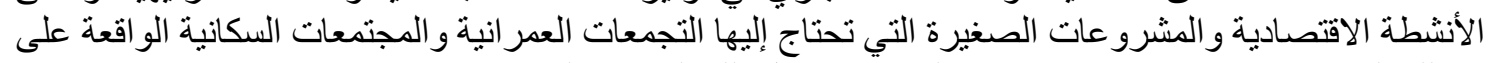

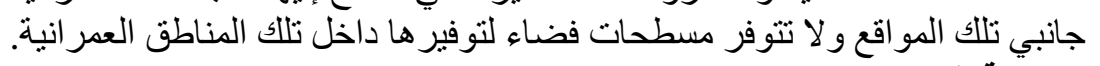

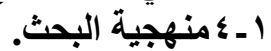

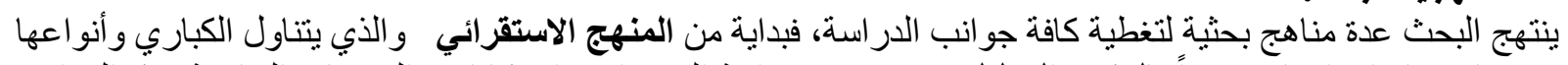

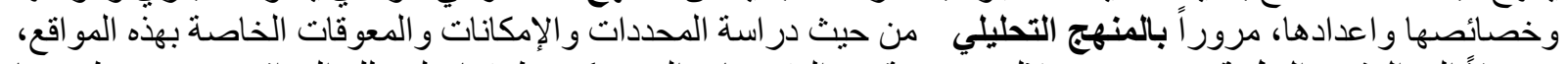

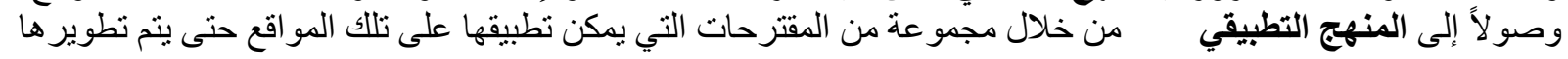


بـ - الكباري والطرق المعلقة.

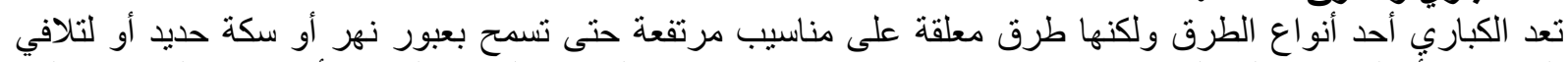

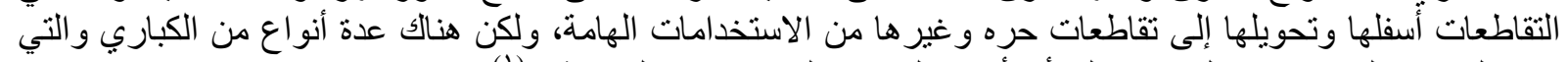

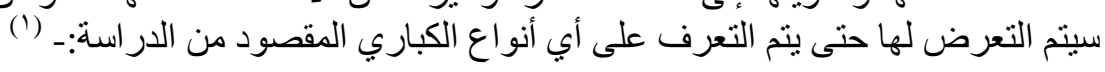

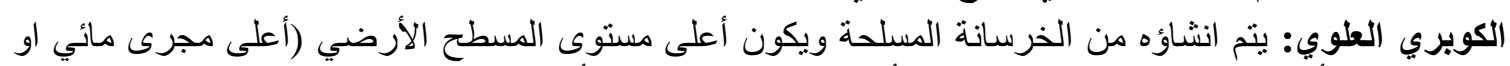

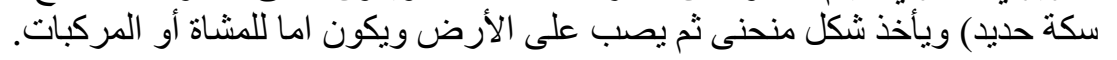

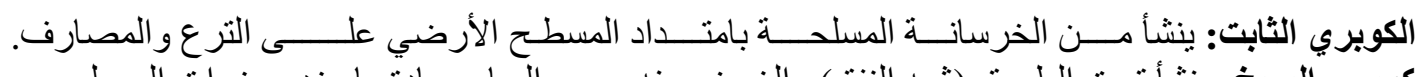

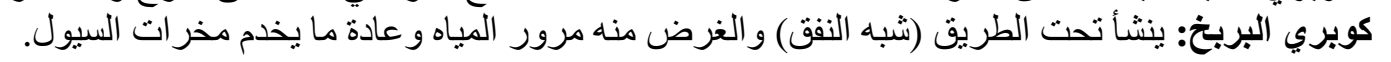

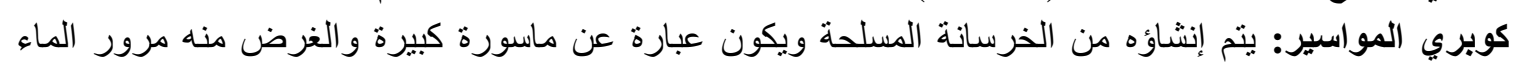

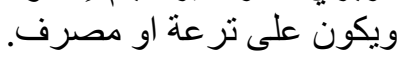
كوبري النفق: ينشأ من الخرسانة المسلحة أسفل منسوب الطريق ويكون مسار للمشاة و النقل الخفيف.

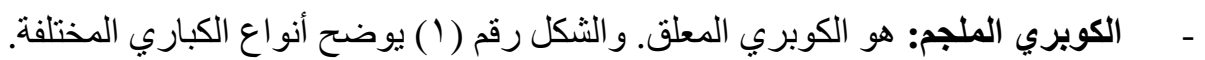

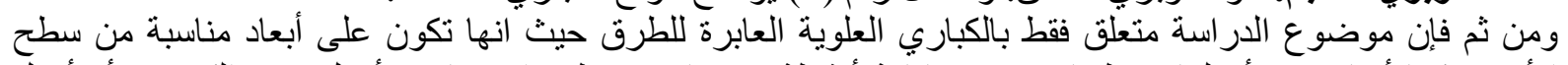

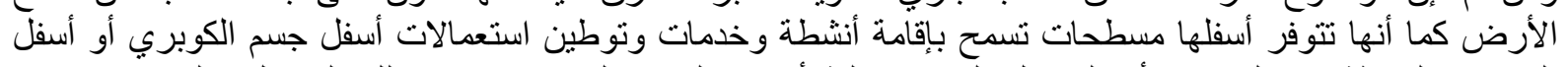

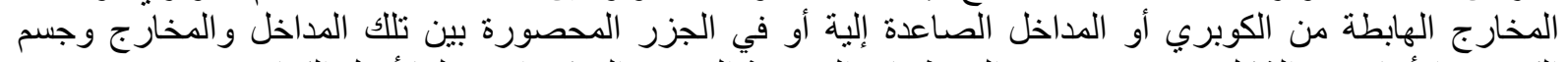

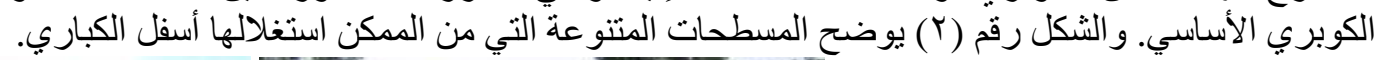

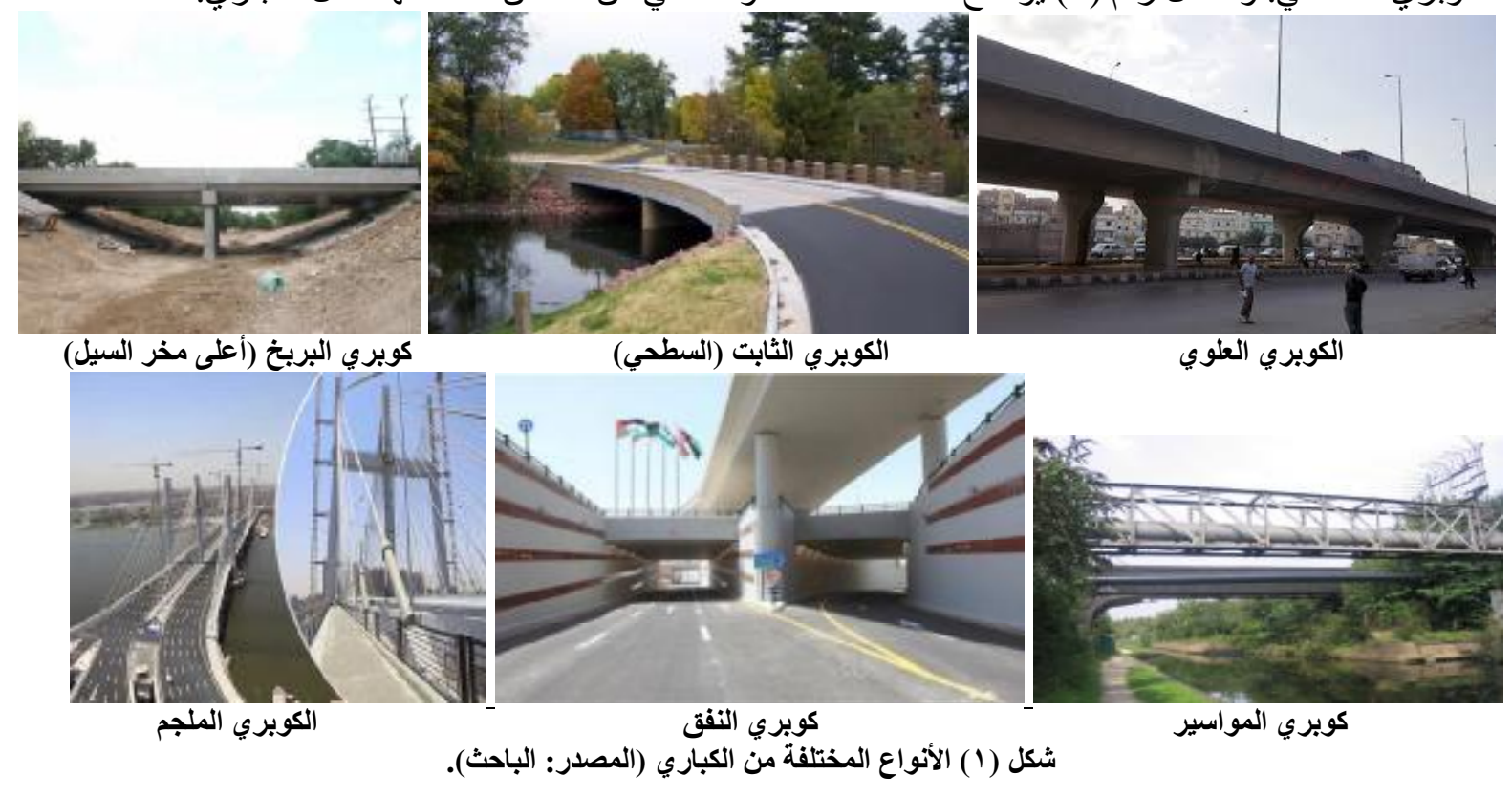

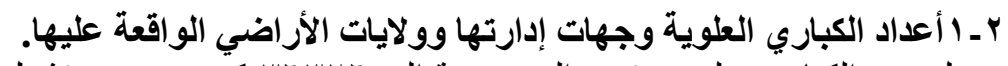

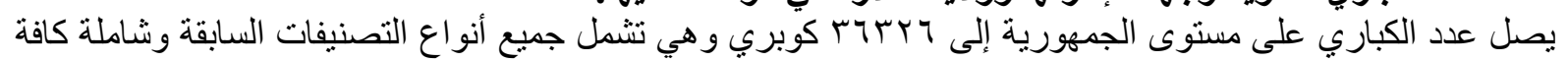

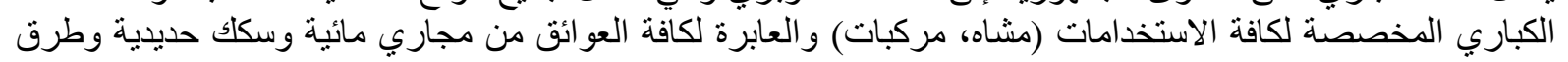

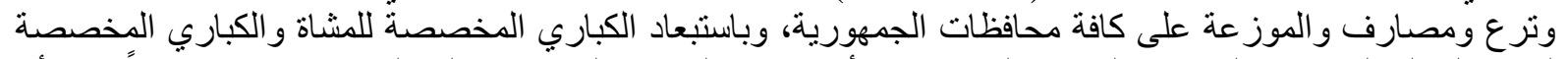

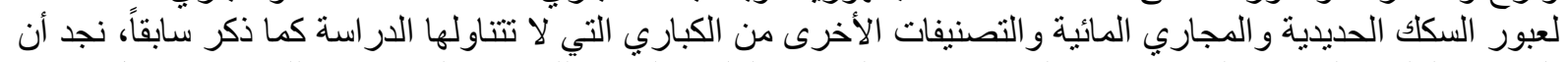

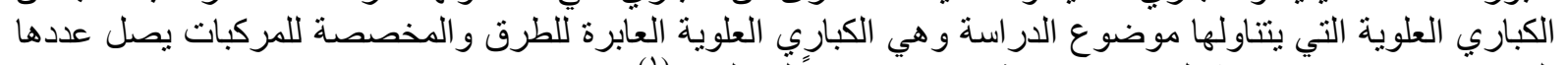

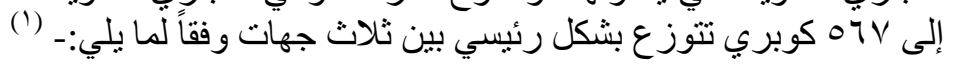

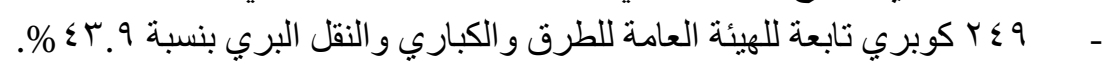

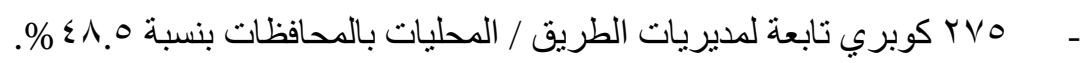

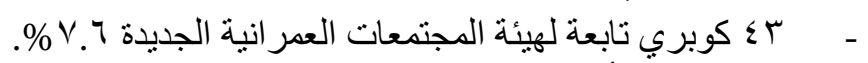

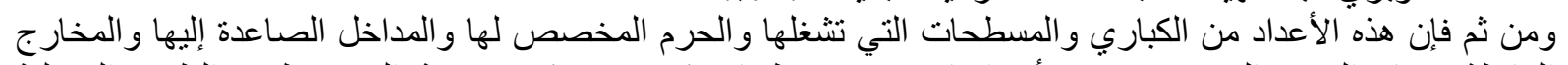

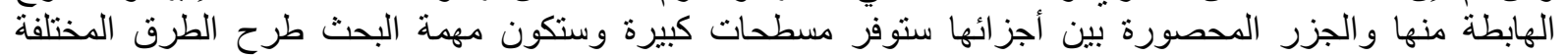
لاستغلالها. 
بـ ب الوضع الراهن للمسطحات الواقعة أسفل الكباري العلوية.

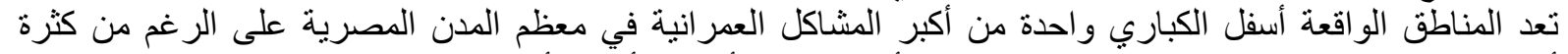

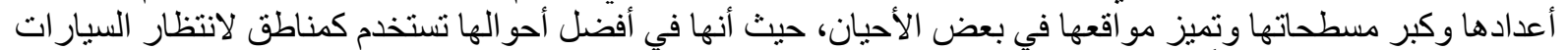

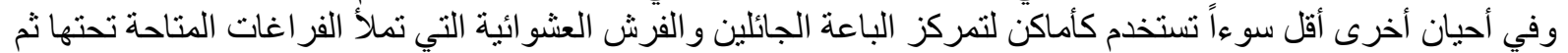

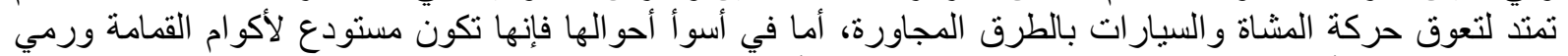

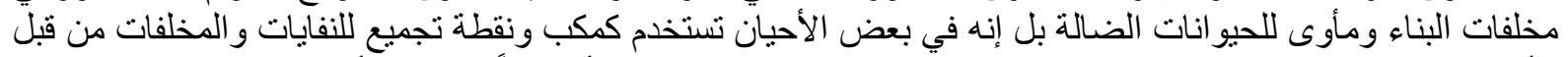

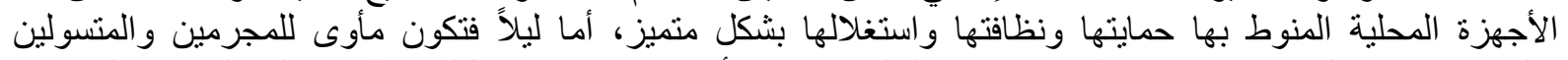

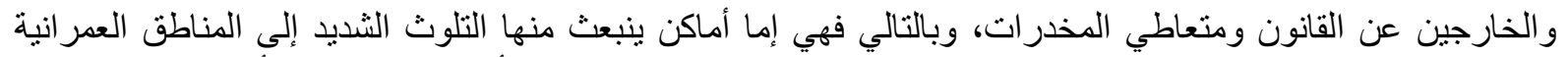

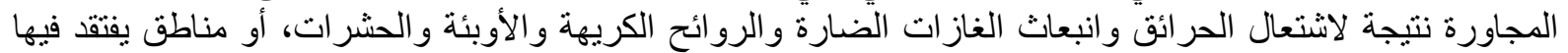

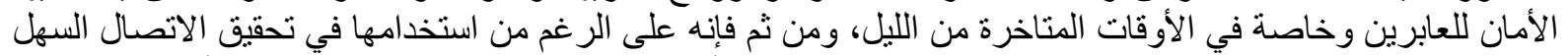

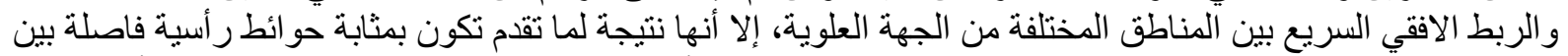

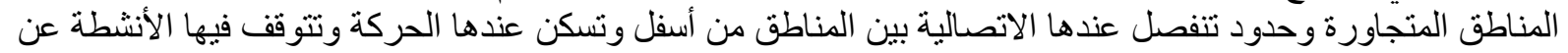

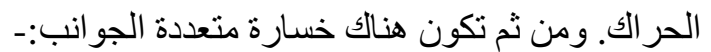
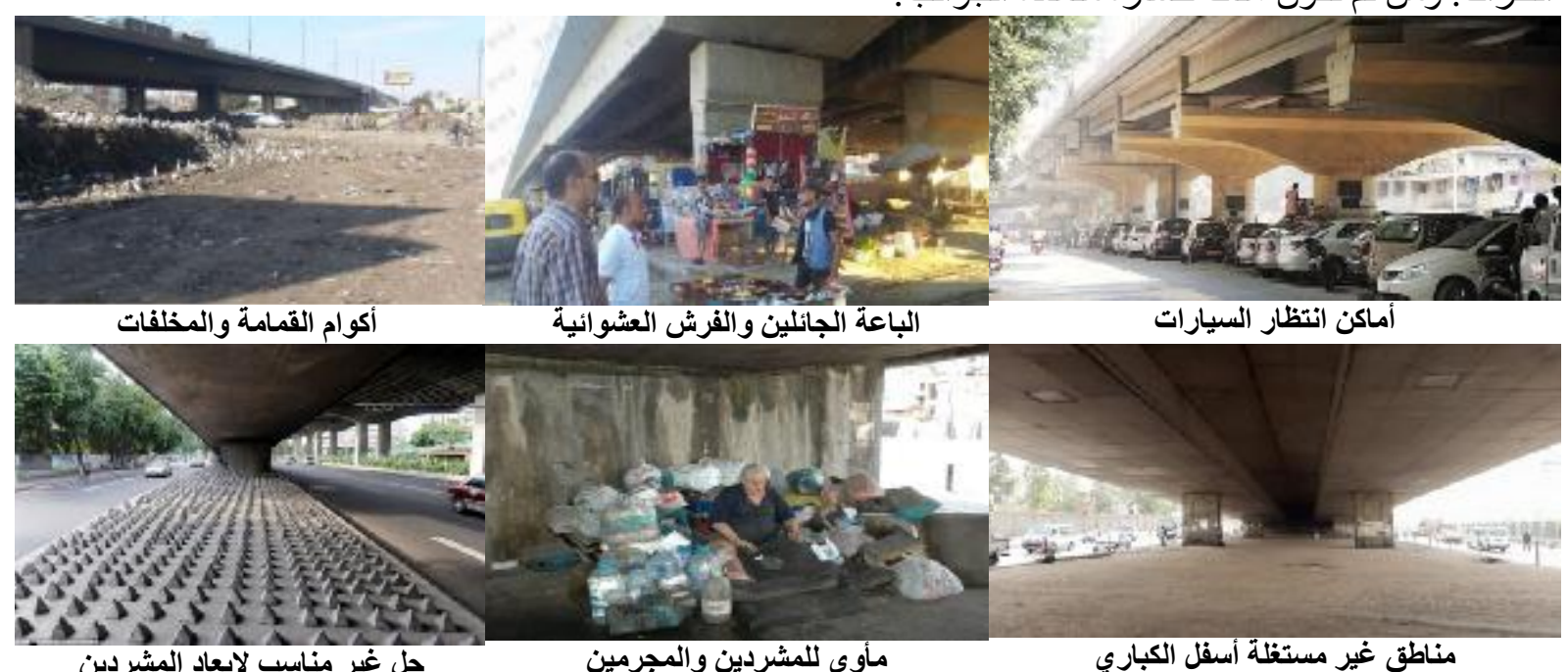

حل غير مناسب لإبعاد المشردين

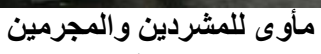
مناطق غير مستظة أسفل الكباري

شكل (ץ) الوضع الراهن لاستغلال المسطحات أسفل الكباري (المصدر: الباحث).

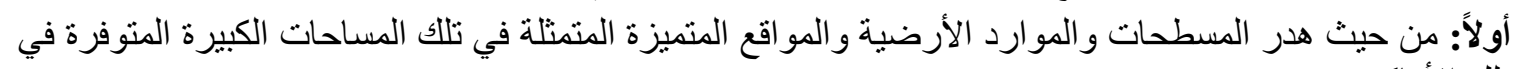
تللك الأماكن. ثانياً: أن عدم استغلالها بشكل جيد يؤدي إلى استعمالها بشكل سيئ وأن عدم استغلالها بشكل مخطط يؤدي إلى استخدامها بشكل عشو ائي.

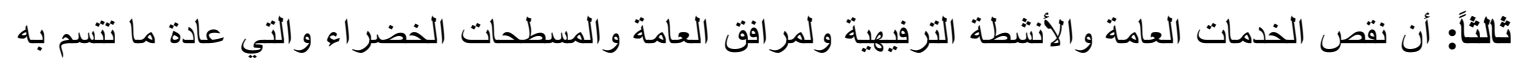

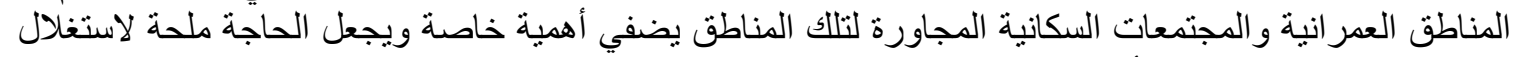

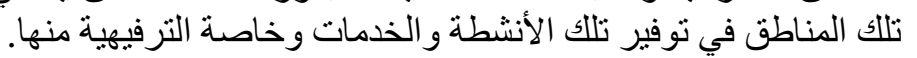

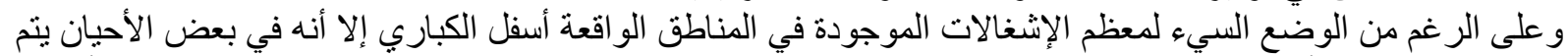

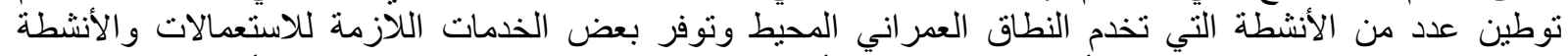

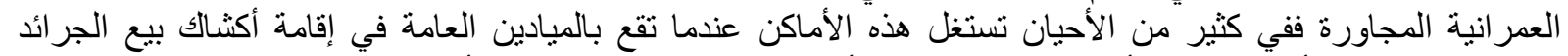

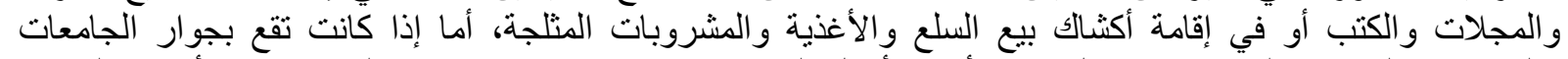

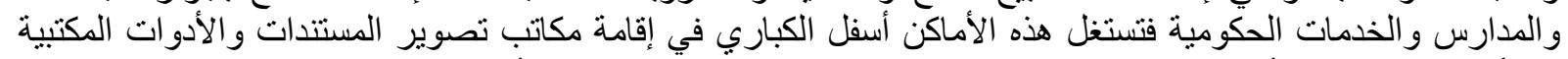

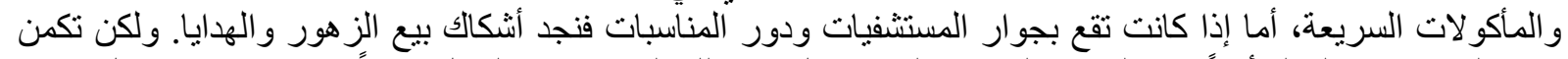

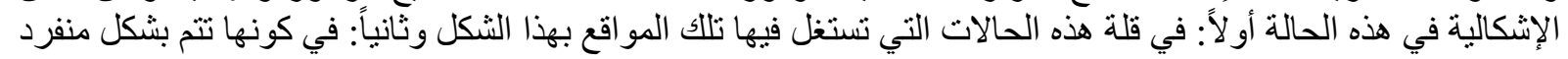

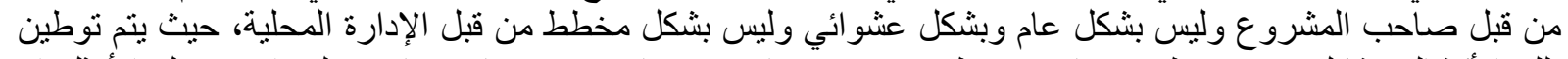

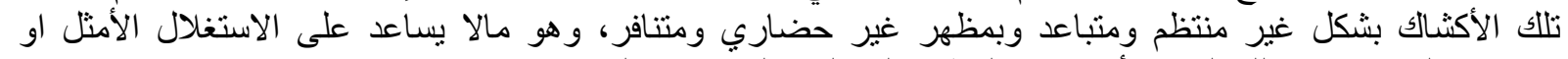
الاستفادة القصوى من تللك المو اقع أو تحقيق المظهر الجمالي و الحضاري وئري المناسب. 

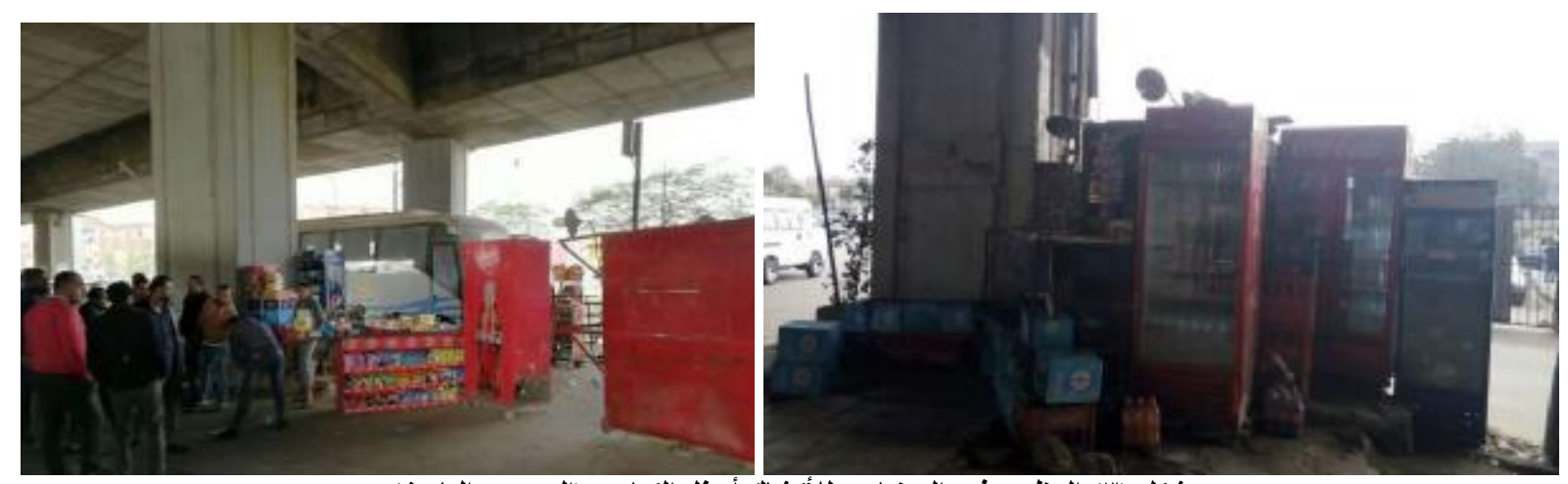

شكل (r) المظهر غير الحضاري للأكثاك أسفل الكباري (المصدر: الباحث).

rـ ــماذج لاستغلال المناطق المتاحة أسفل الكباري العلوية.

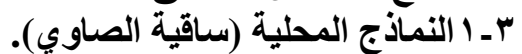

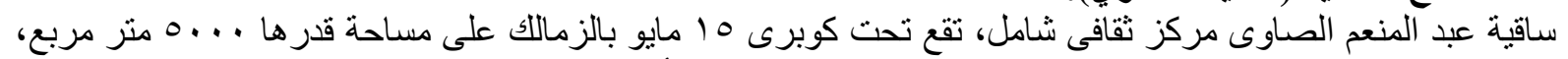

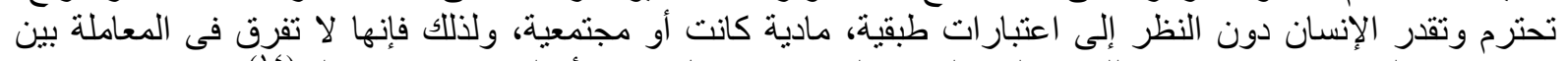

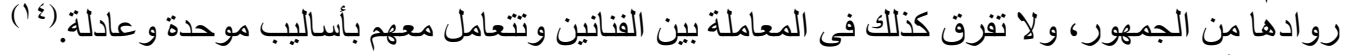
ß

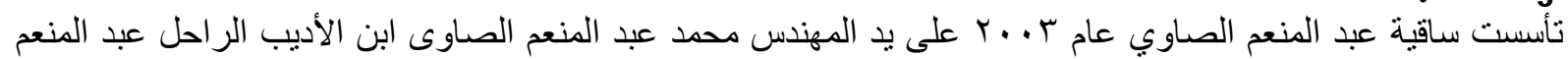

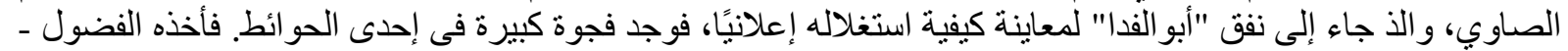

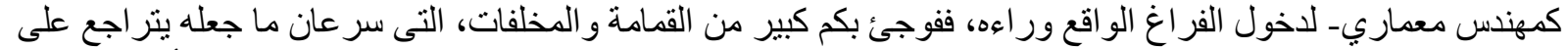

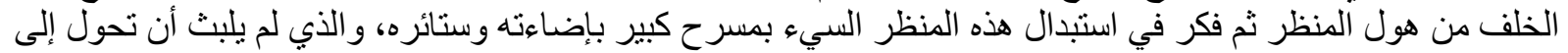

حقبقة.

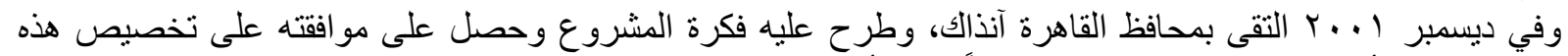

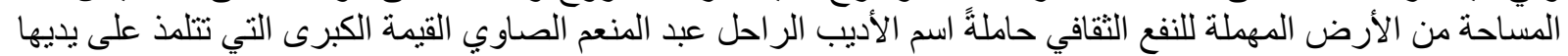

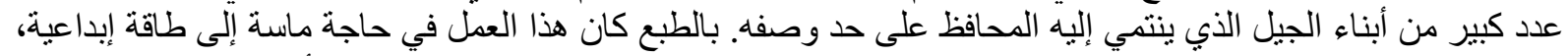

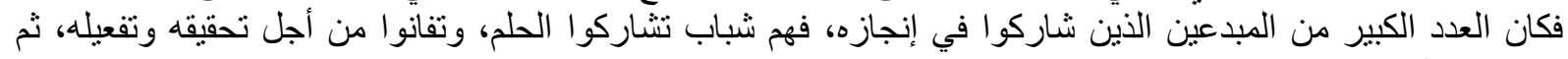

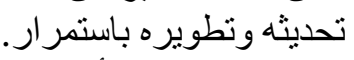

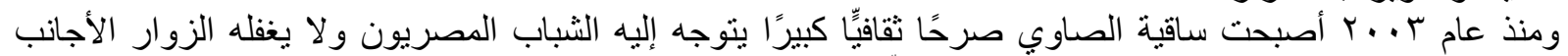

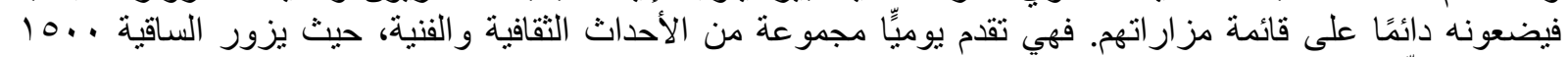

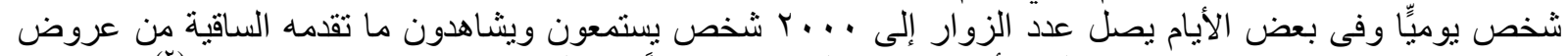

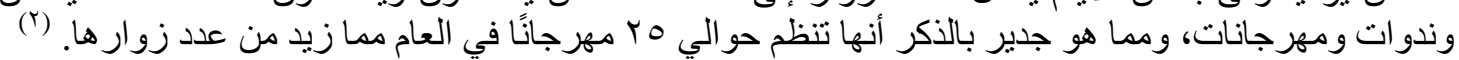

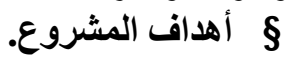

- الحفاظ على الهوية المصرية العربية، بما لها من عمق حضاري يمتد لآلاف السنين. - - استنئصال الأفكار السلبية من القيم الموروثنة، واستحداث أفكار أخرى مبتكرة وإيجابية.

- - مضع مقاييس جديدة وجذابة لحملات التوعية، و الحث على الإبداع وبناء الإنسان. - استعادة وضع مصر الرائد بين الدول العربية والإفريقية و القادر على المنافسة في مجالات الإبداع والابتكار إقليميًا

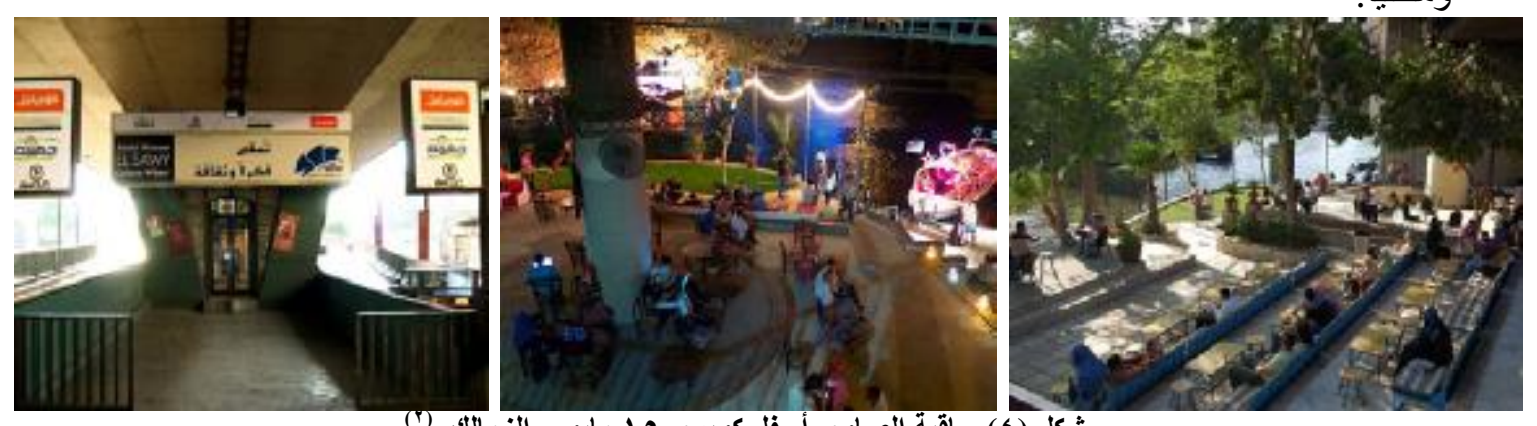

شكل (ع ) ساقية الصاوي أسفل كوبري 10 مايو - الزمالك. (i) 
B أنشطة المركز

يقوم المركز بتقديم العروض الفنية المسرحيةو السينمائية و الموسيقية، و تنظيم المعارض التشكيلية سواء لكبار الفنانين

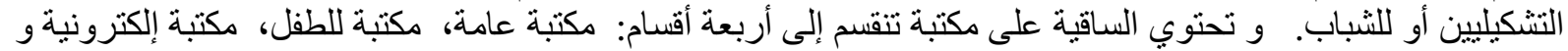

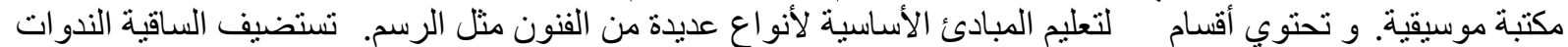
وورش العمل في قاعاتها وهذا على المستوى الأدبي و العلمي. بالإضافة إلى تقديم العروض المسني العسرحية، يقوم المركز بتنظيم المسابقات في المجال المسرحي.

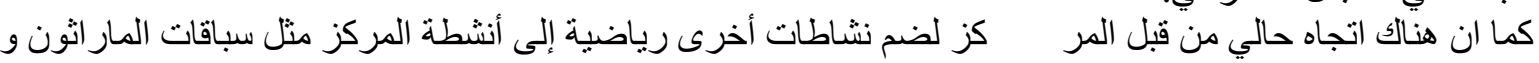

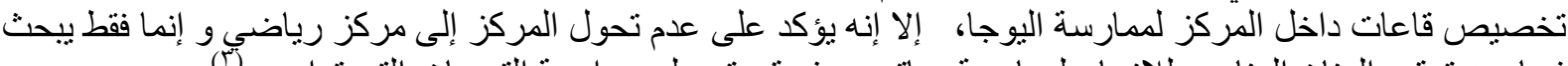

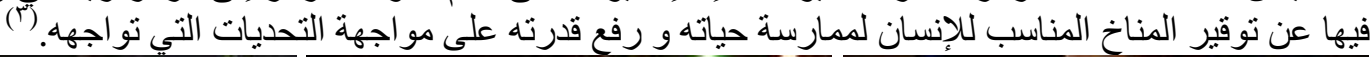
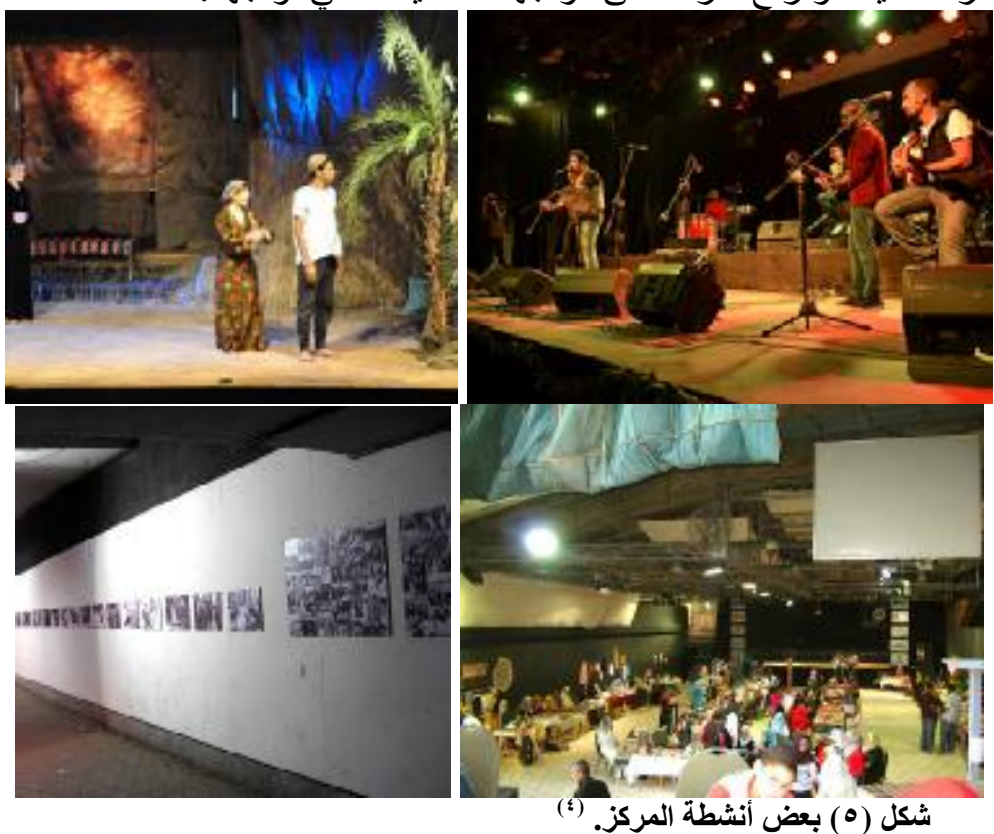

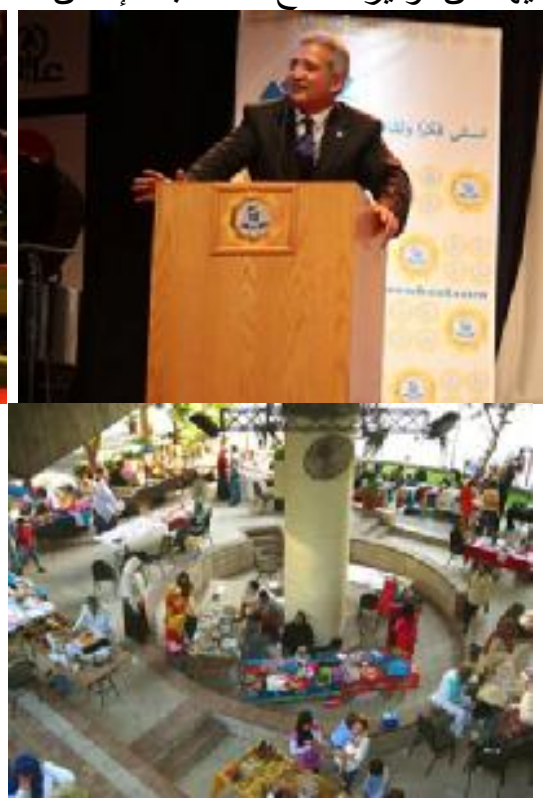

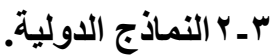

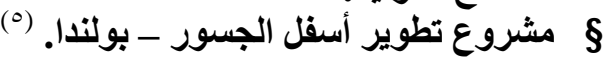

رأى القائمين على المشروع أنطول الجسور التي تتخلل الهياكل الحضرية على الرغم من قربها الثنديد من المجتمعات السكانية

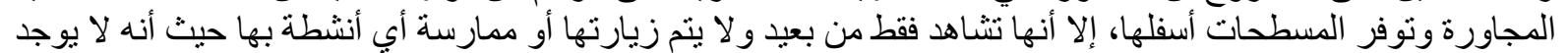

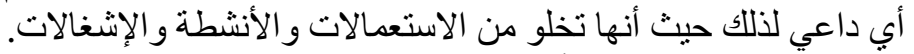

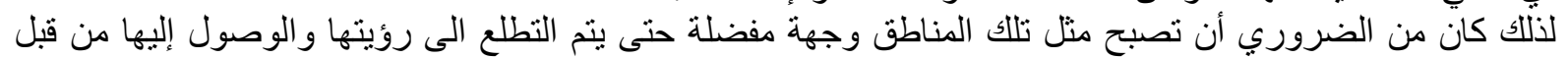

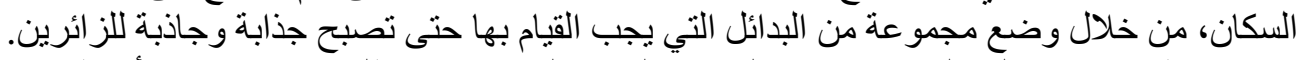

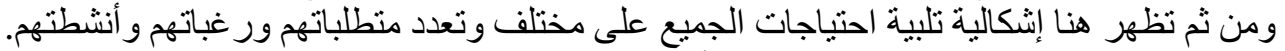

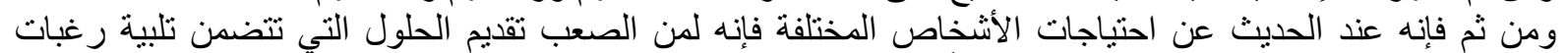

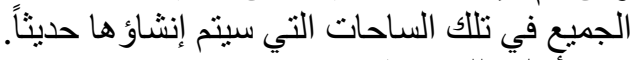

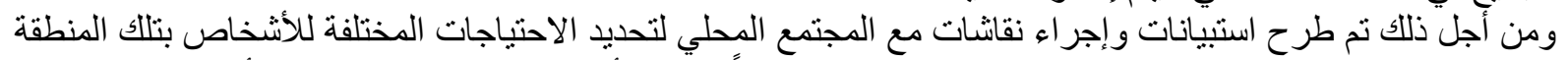

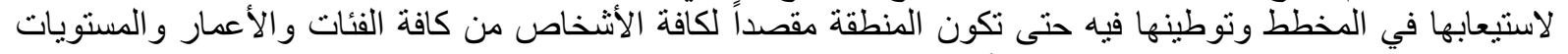
الاجتماعية في مكان واحد، وكان استطلاع آر اء الناس في ذلك حتى يشعر المو اطنين بالانتماء للمكان الذي يمارسون فيه

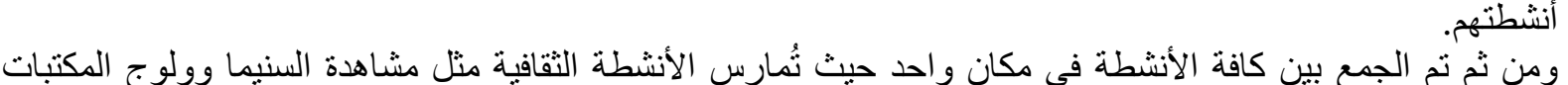

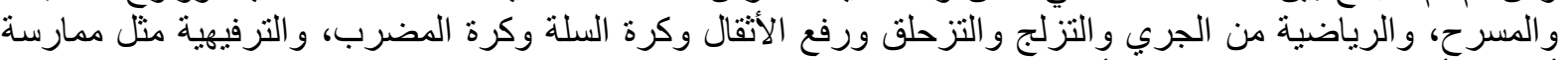

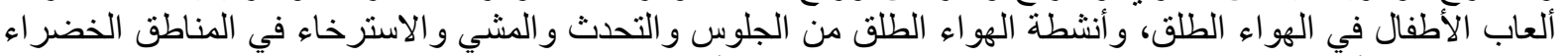

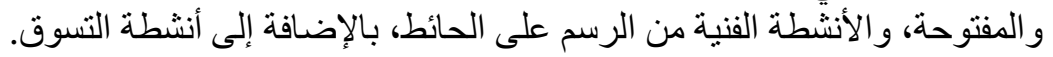

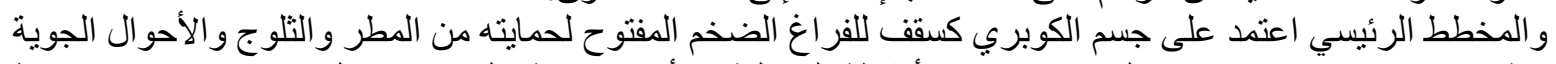

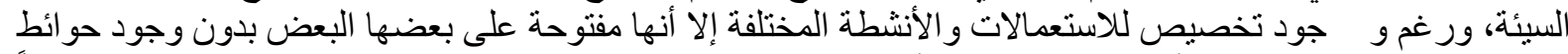

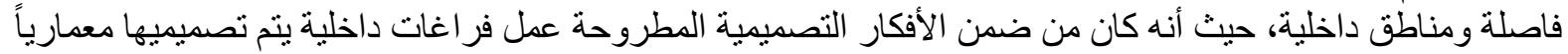

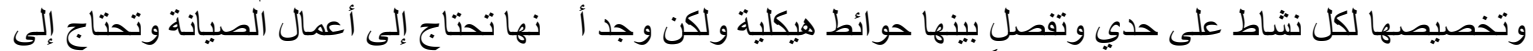

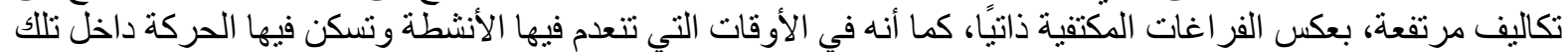




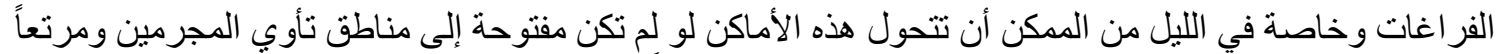

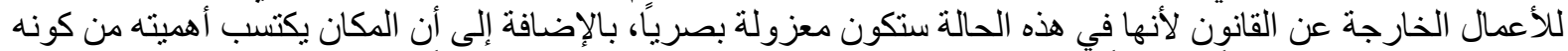

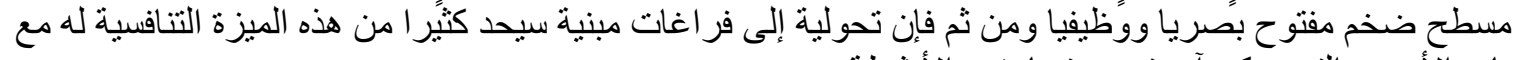


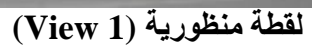



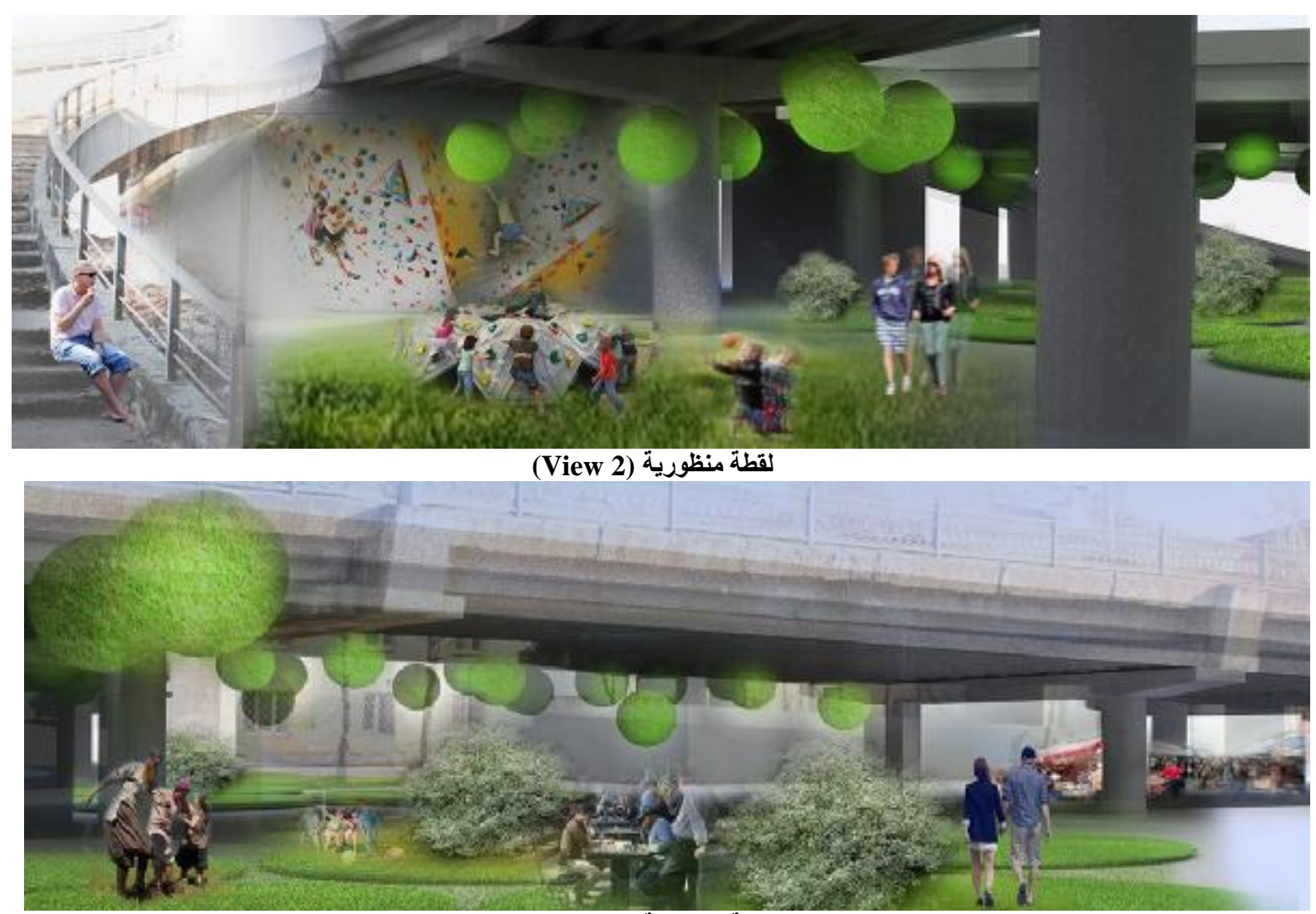

لقطة منظورية (View 3) ( لقاية

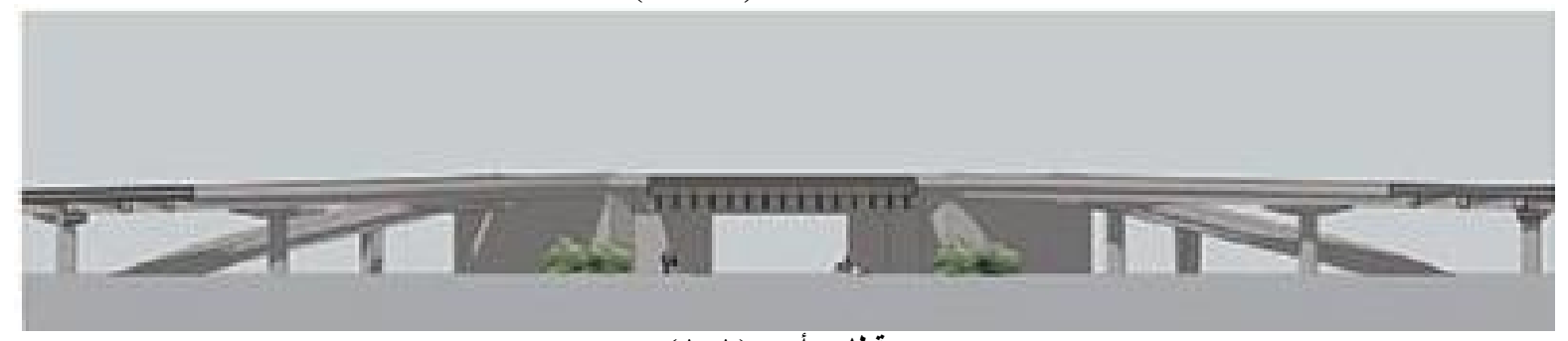

قطاع رأسي (A-A)

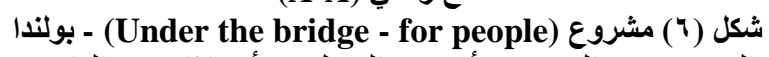

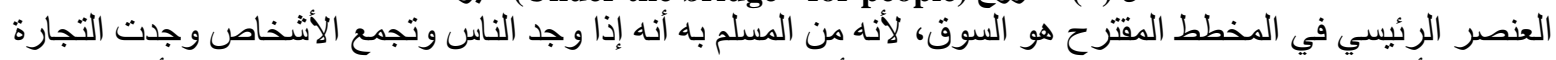

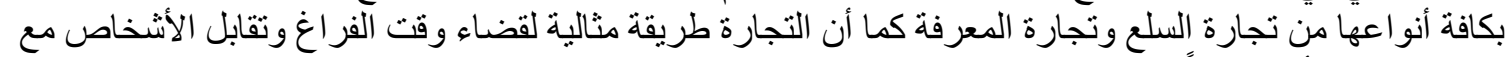

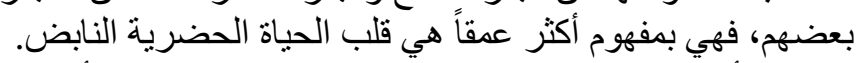

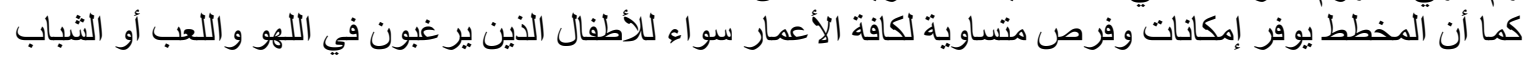

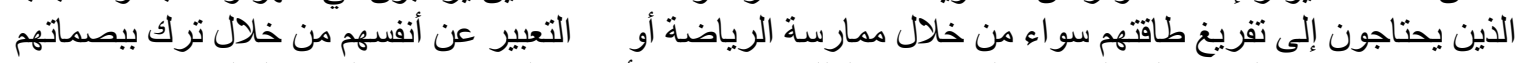

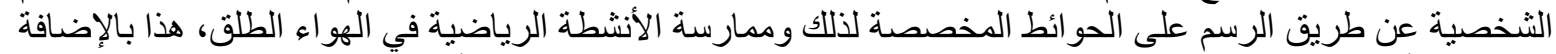

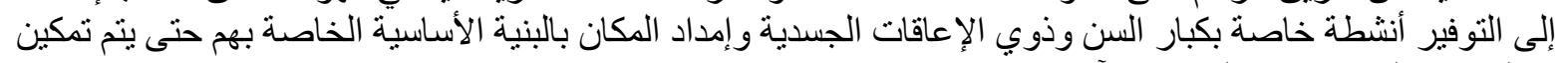

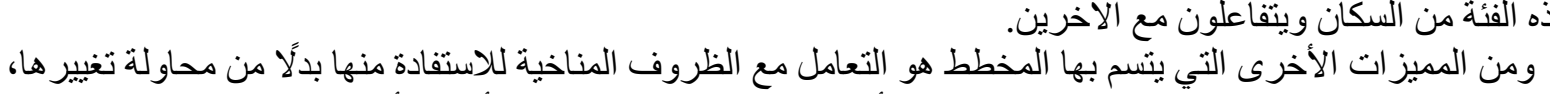

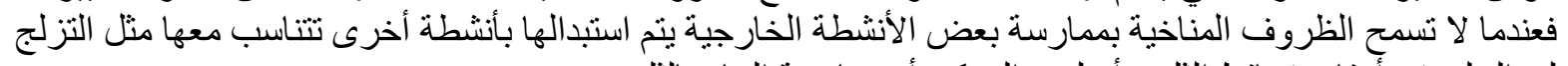

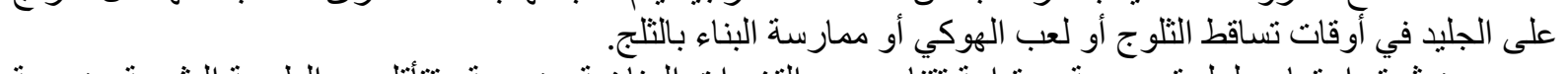

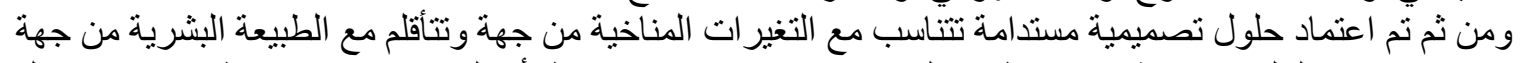

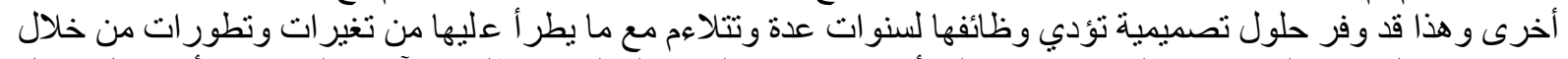

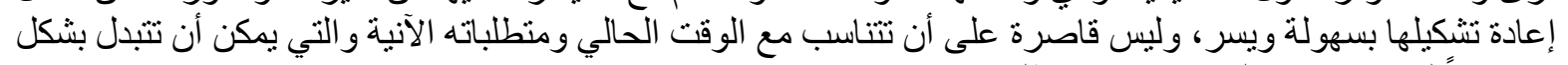
سريع و فقاً لتغير رغبات بنهات المستخدمين و منطلباهم. 
ـ ـ الاستغلال الأمثل للمسطحات الأرضية أسفل الكباري العلوية.

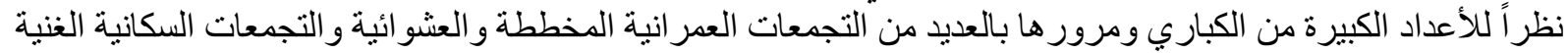

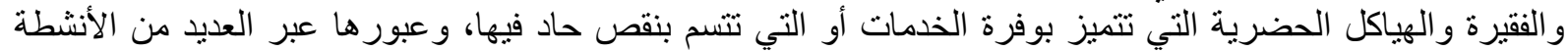

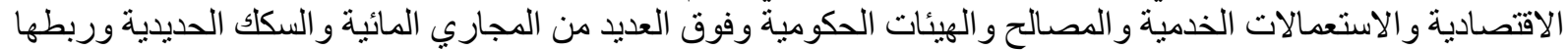

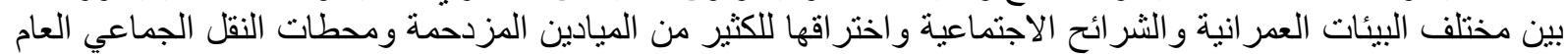

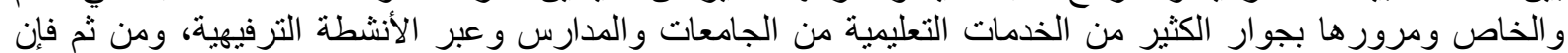

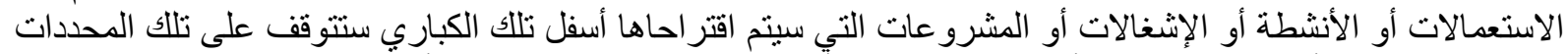

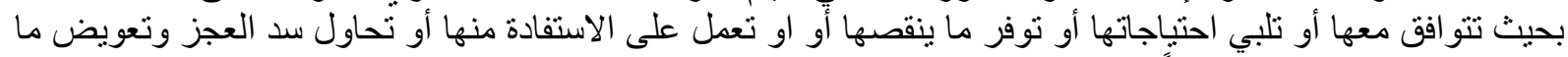

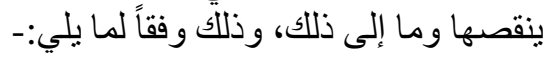

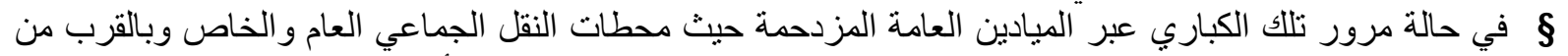

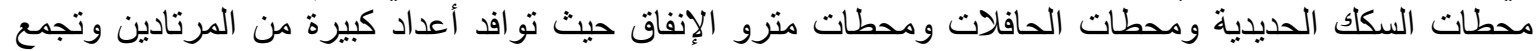

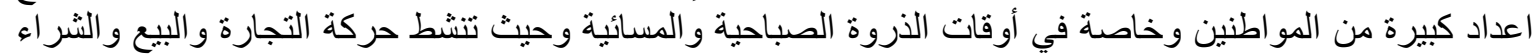

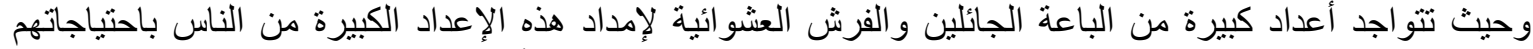

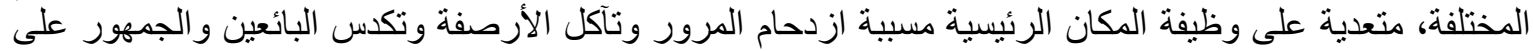

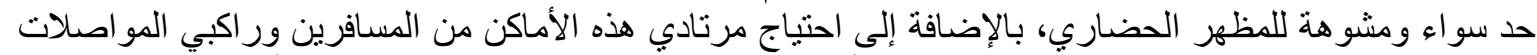
إلى المر افق العامة من دور ات المياه وفي كثير من الأحيان تتحول تللك المناطق تحت الكئ الكباري إلى أماكن لقضاء القياء الحاجة

ورمي المخلفات.

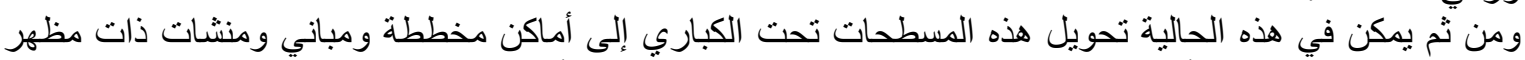

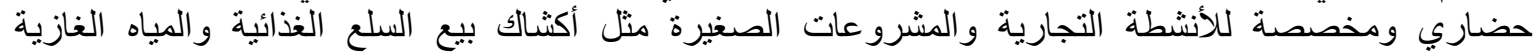

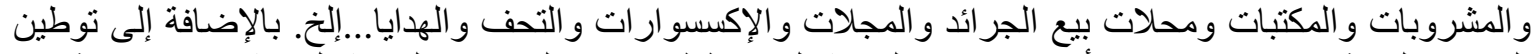

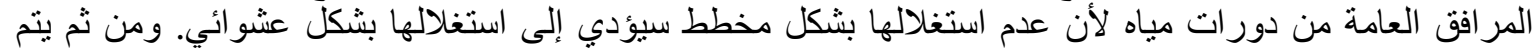

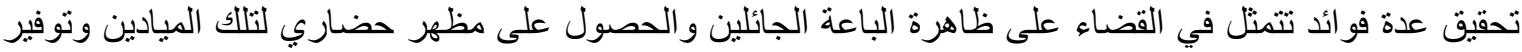

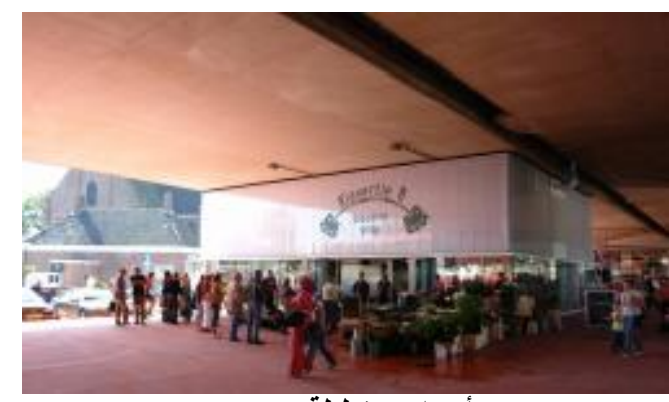

أسواق مخططة مشرو عات صغيرة توفر فرص فئن فمل للبطالة.

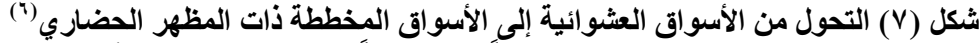

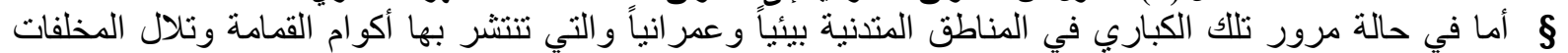

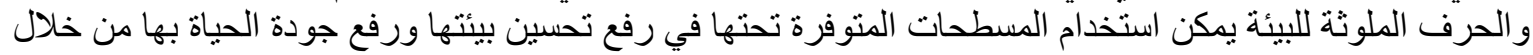

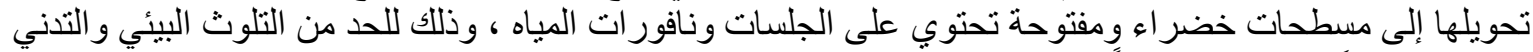

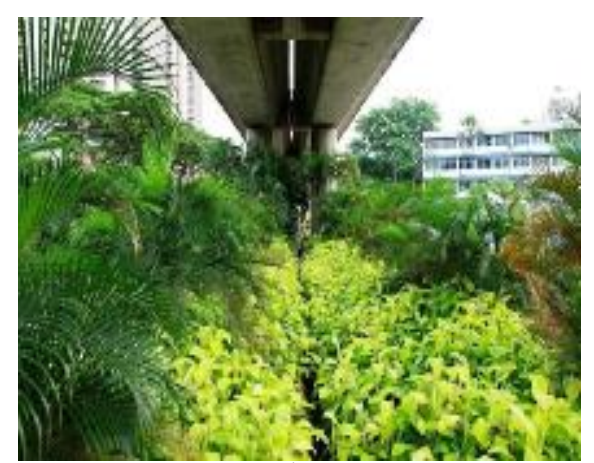

مناطق خضر اء أسفل الكباري

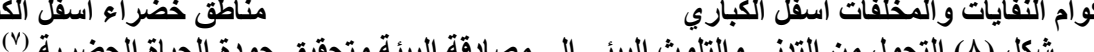
العمر اني وبدلاً من تحولها مرتعاً للخارجين عن القانون. 


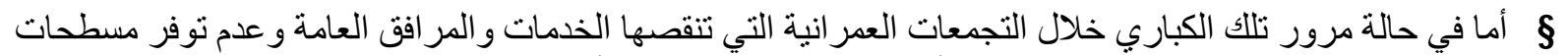

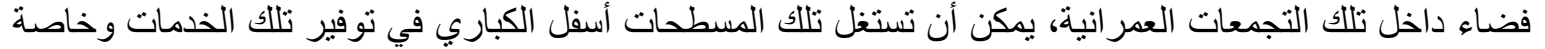

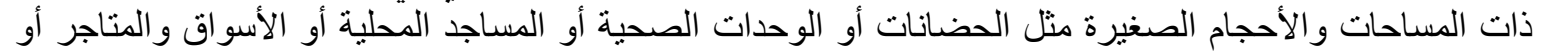
مو اقف النقل العام...و غير ها من الخدمات و المر افق العامة.
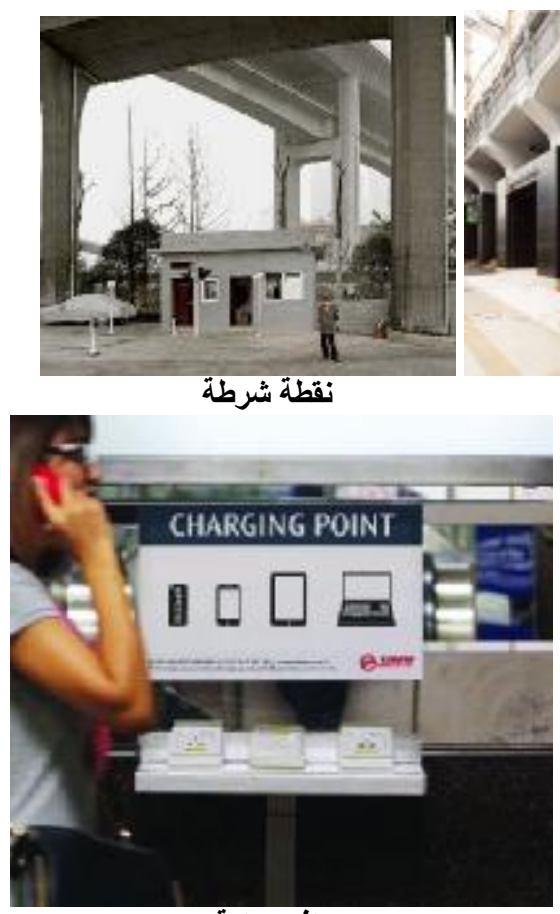

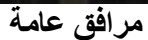

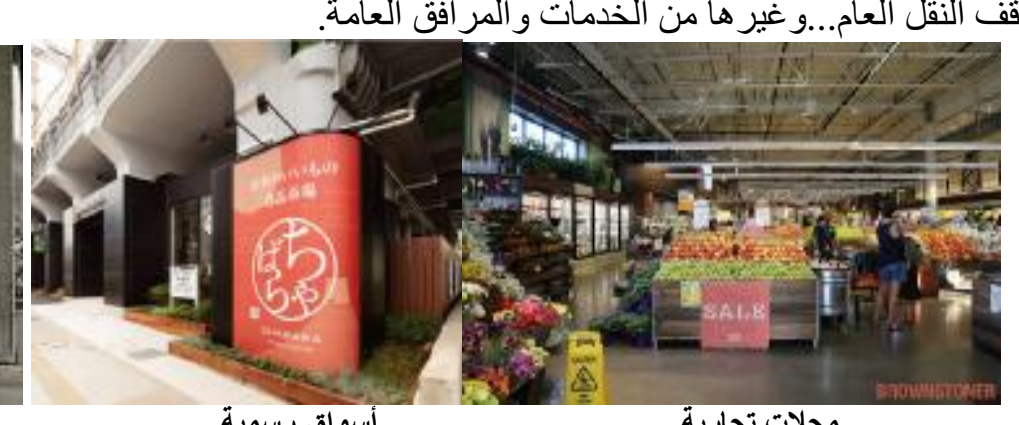

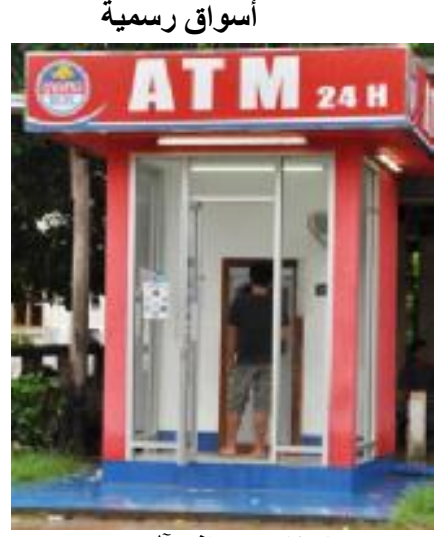

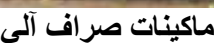

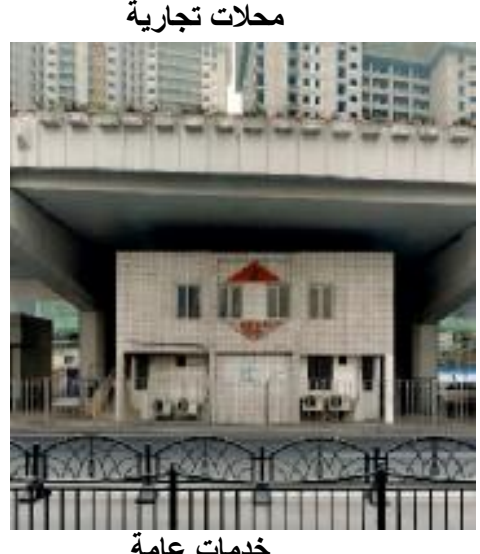

شكل (9) بعض الخدمات التي من المكن توفيرها في التمسطحات المتاحة أسفل الكباري العلوية (ه)، (9).

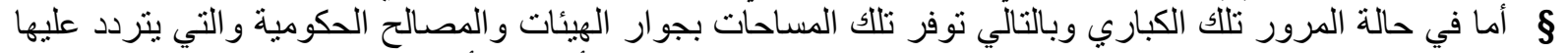

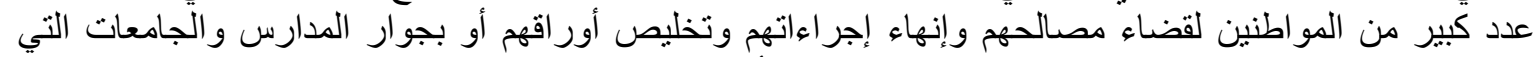

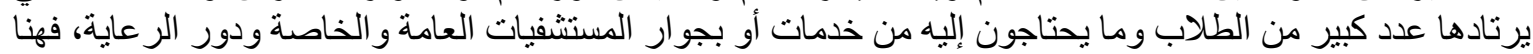

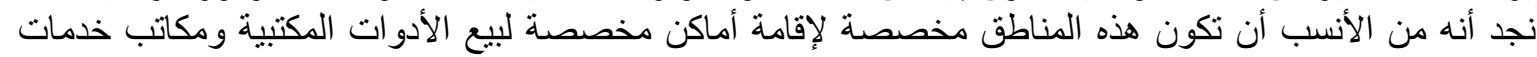

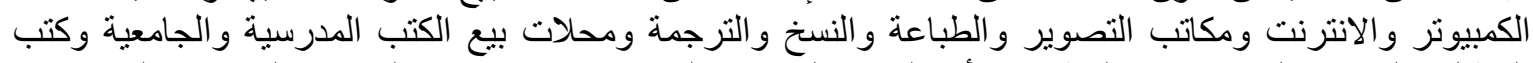

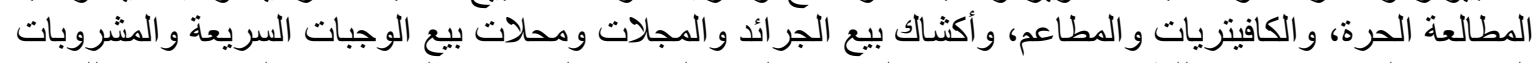

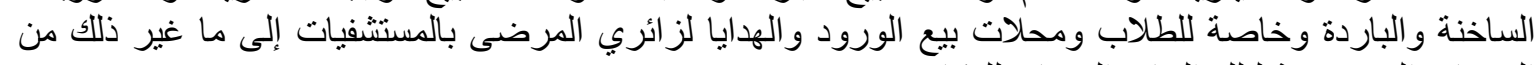

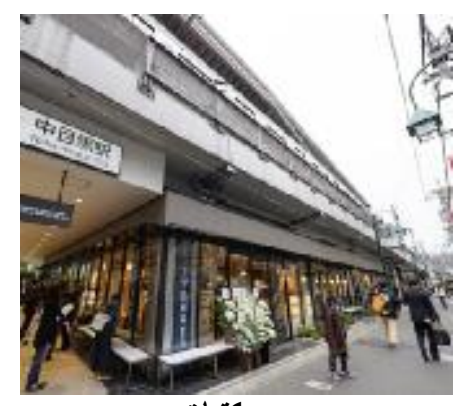

مكتبات

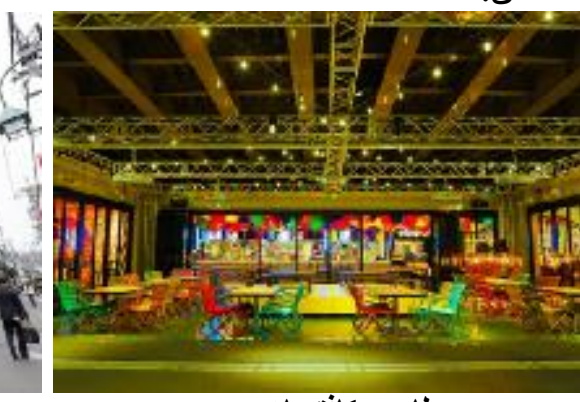

مطاعم وكافتريات الخدمات المخصصة لتلإد الفئات المرتادة للمكان

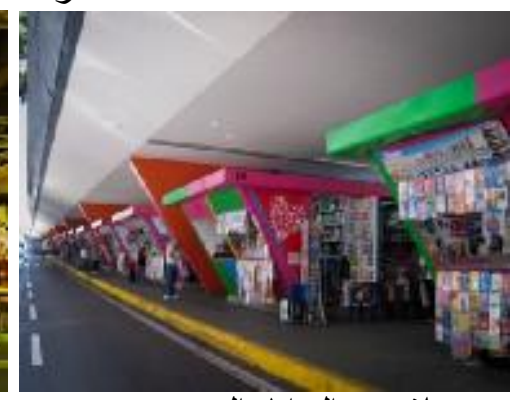

محلات بيع الهايا والورود

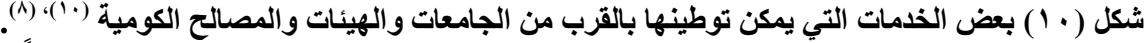

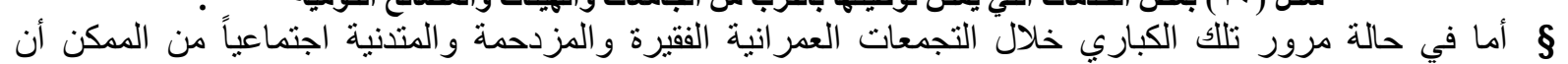

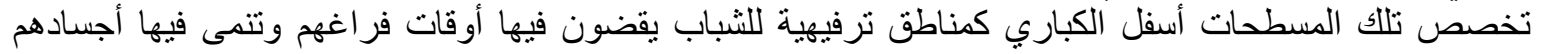

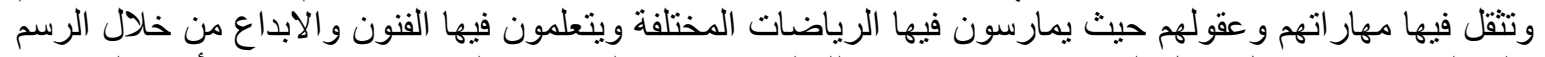

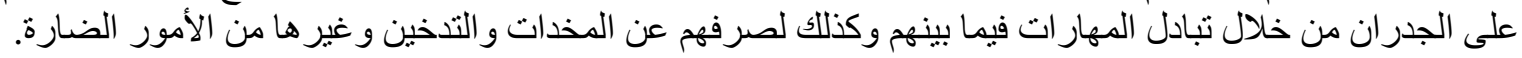



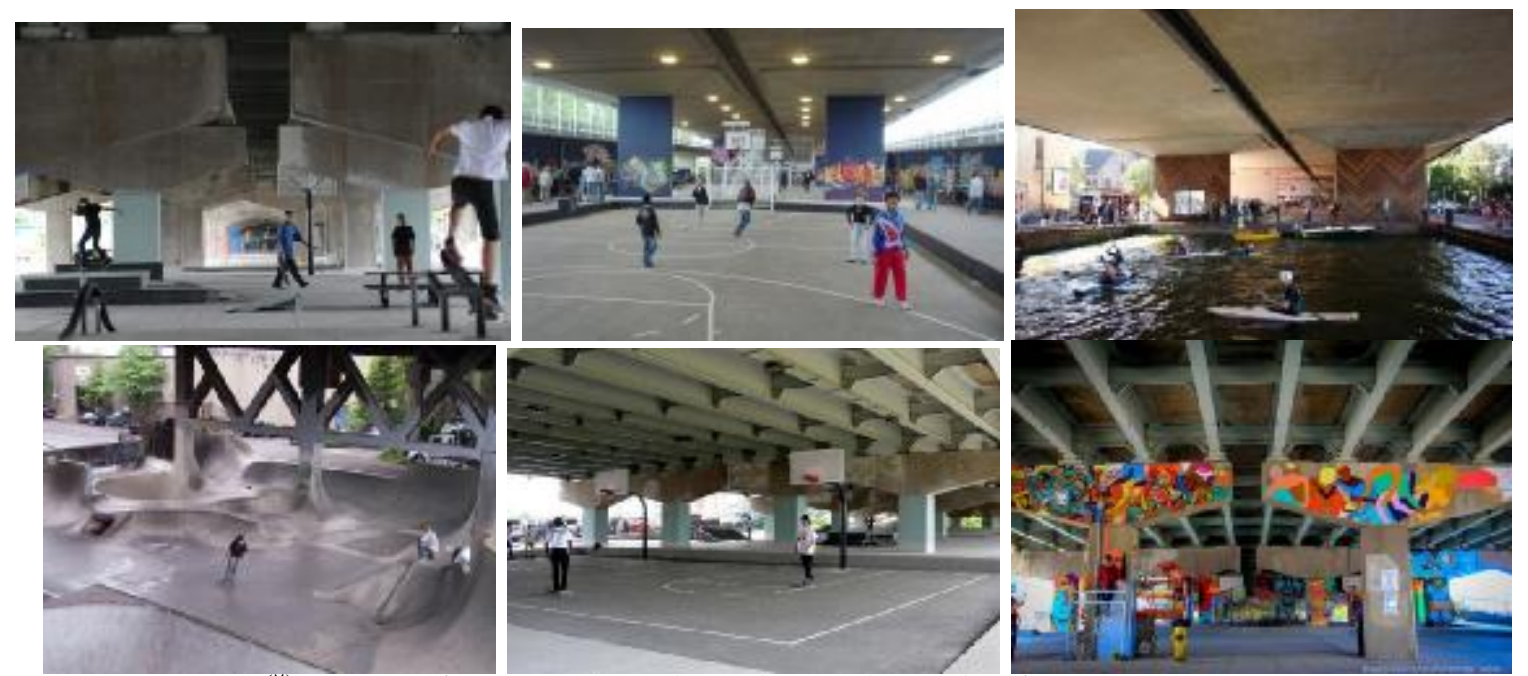

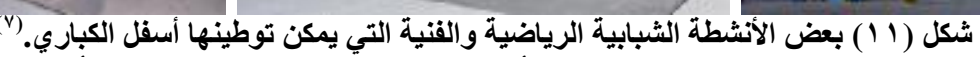

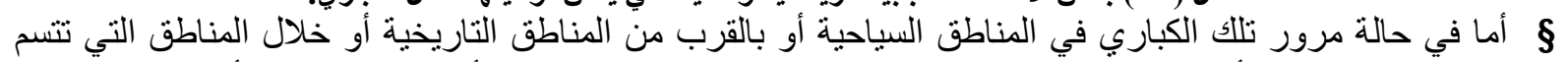

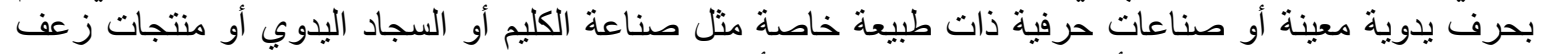

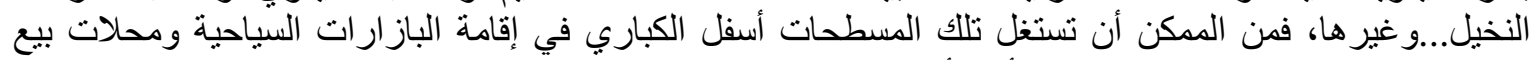

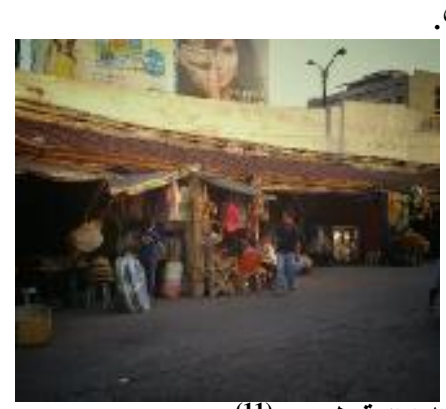

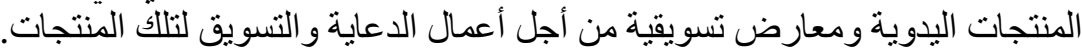
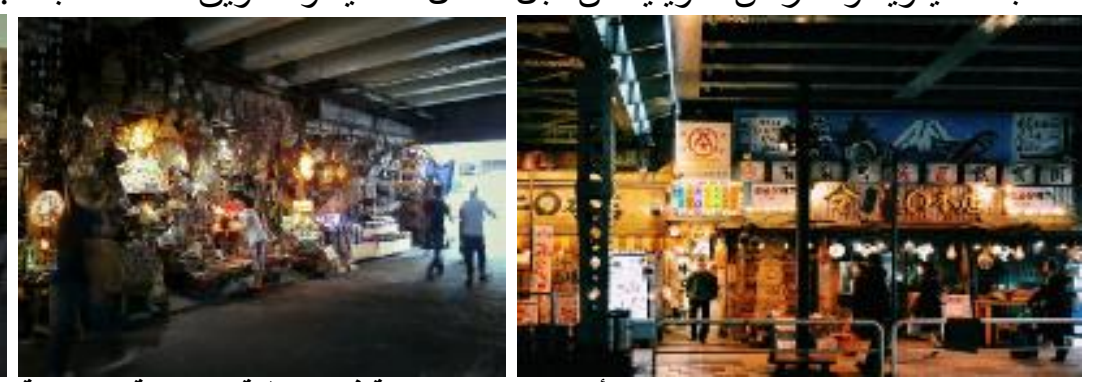

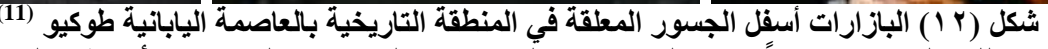

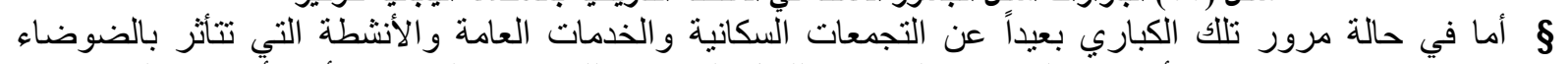

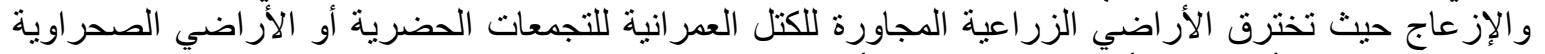

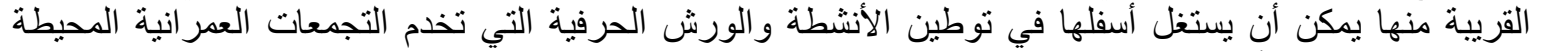

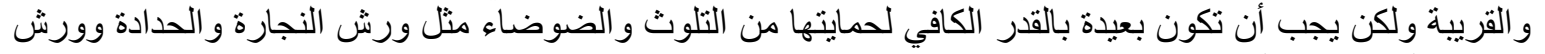

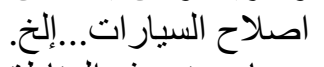

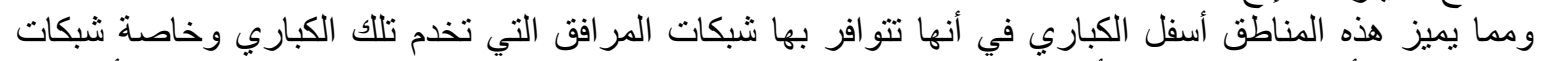

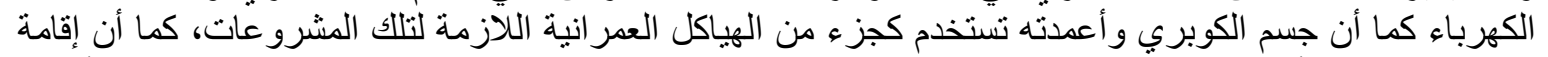

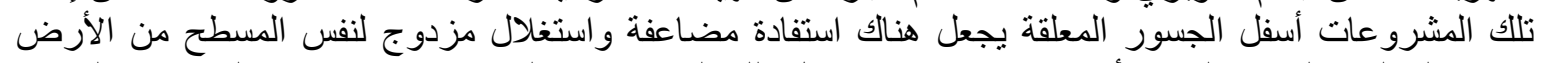

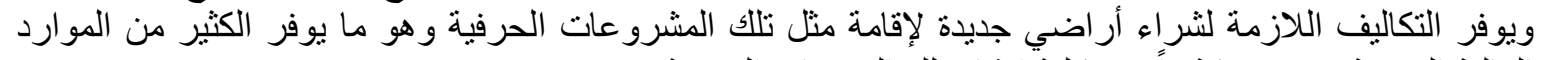

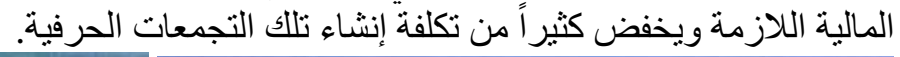
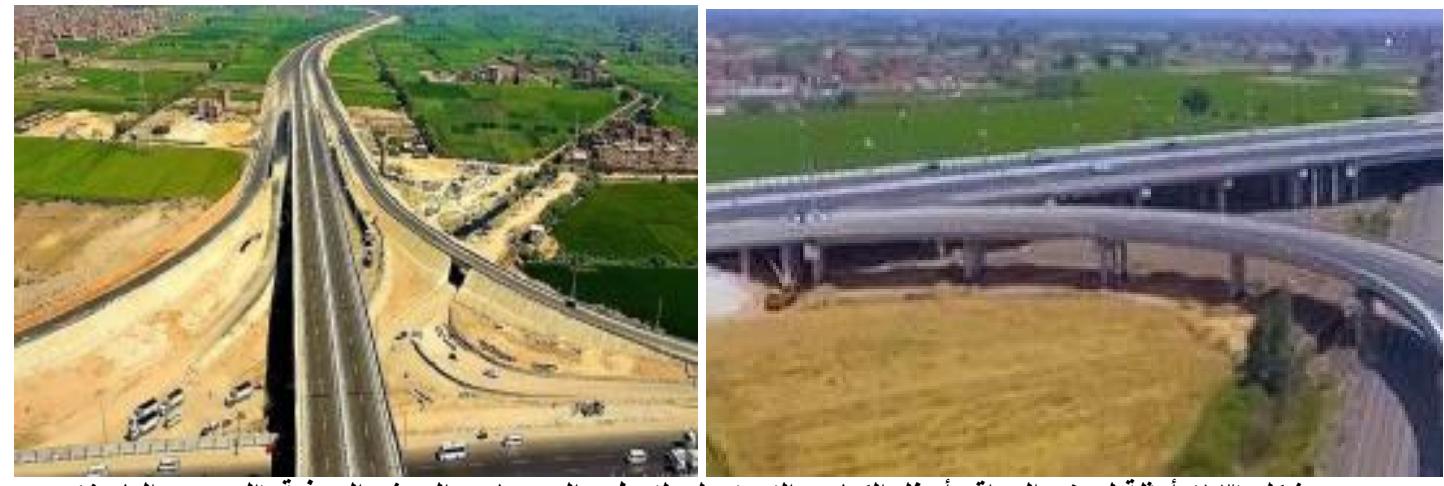

شكل (ب ا ) أمثلة لبعض المواقع أسفل الكباري التي تصلح لتوطين المجمعات والورش الحرفية (المصدر: الباحث). 


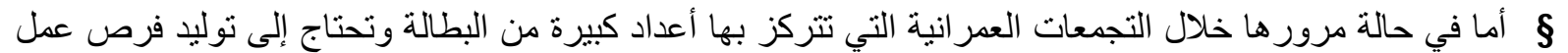

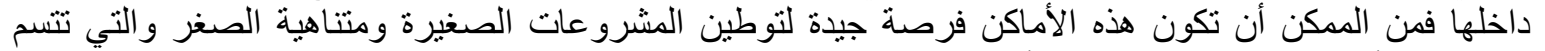

بانخفاض ر أس مال المشروع وان وارتفاع أعداد العاملين بها.

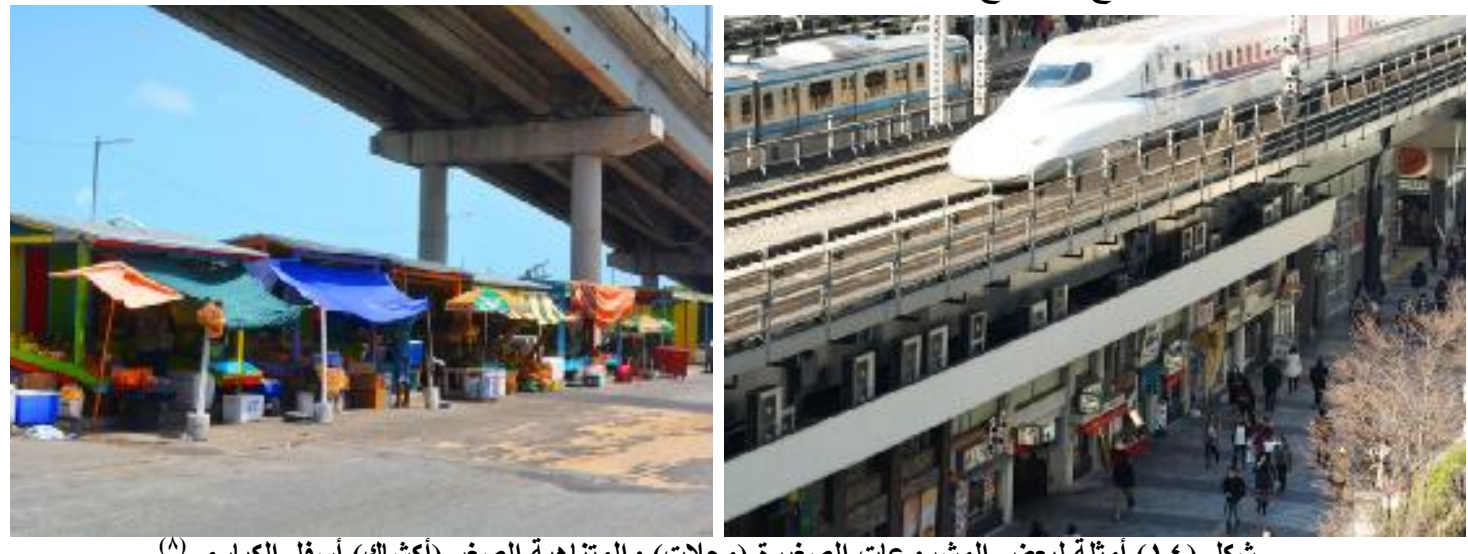

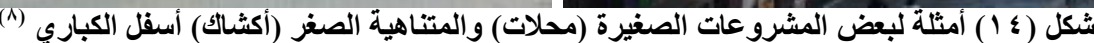

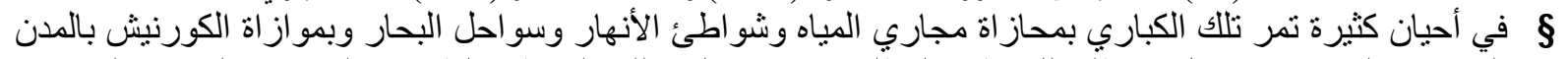

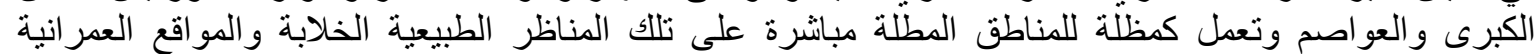

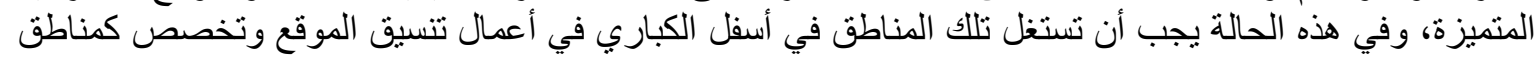

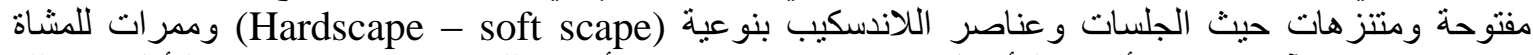

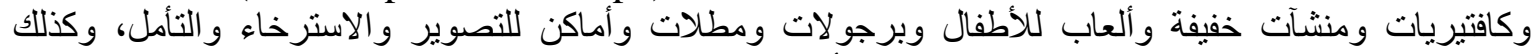

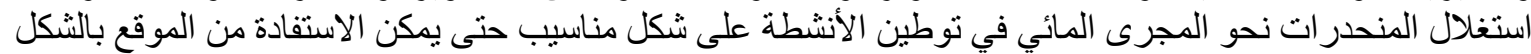
الأمثل ودون أن يختفي أبي استعمال ور اء الآخر.
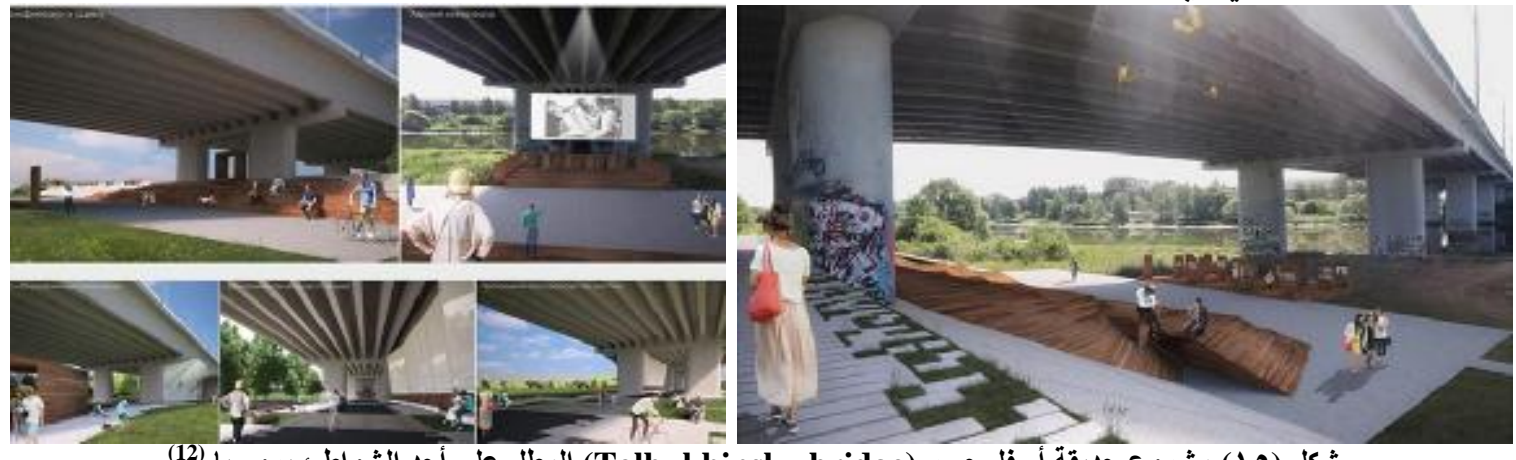

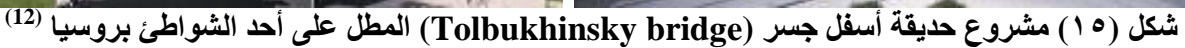

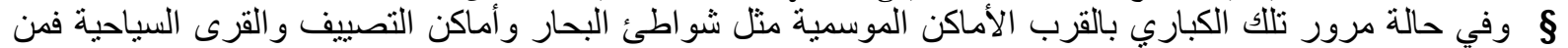

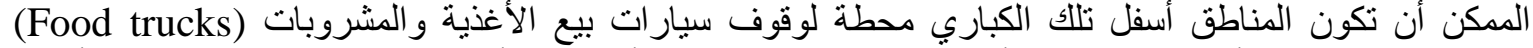

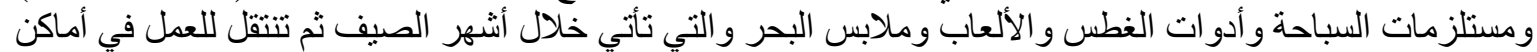

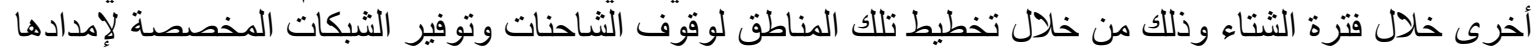

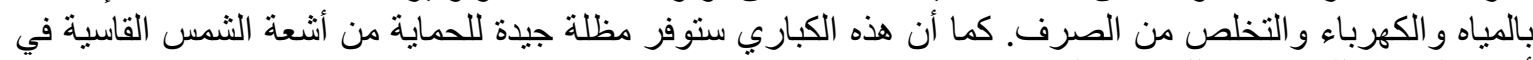

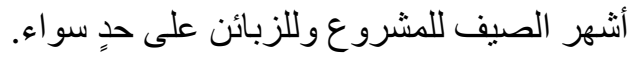
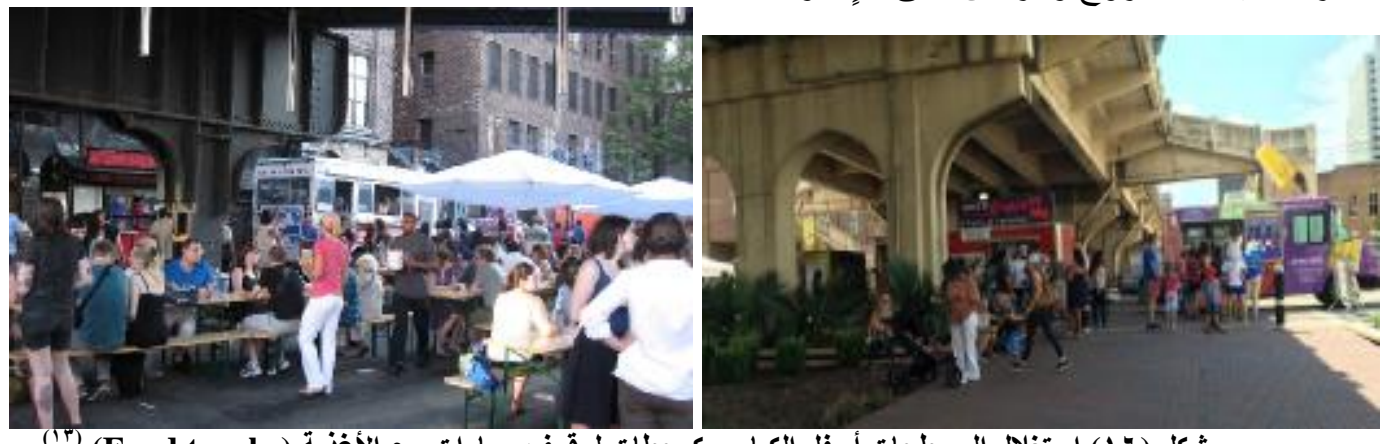

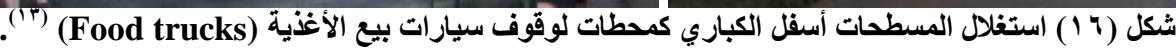

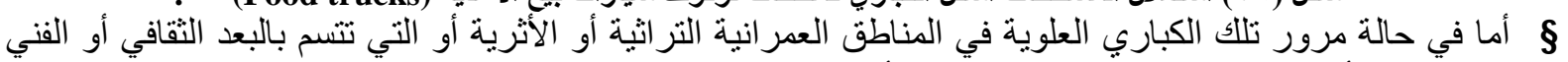
فمن الممكن أن تستخدم تللك المو اقع في توطين الأنشطة الثقافية و الفنية مثل قصور الثقافة والثية المسار ح و المكتبات وقاعات 
إقامة ورش العمل الفنية و التمثيل أو مزيج منها جميعاً، ويعد أحد أهم الأمثلة على ذلك مشروع (ساقية الصاوي) أسفل كوبري 10 مايو بمنطقة الزمالك أحد المناطق التر اثية في مصر.
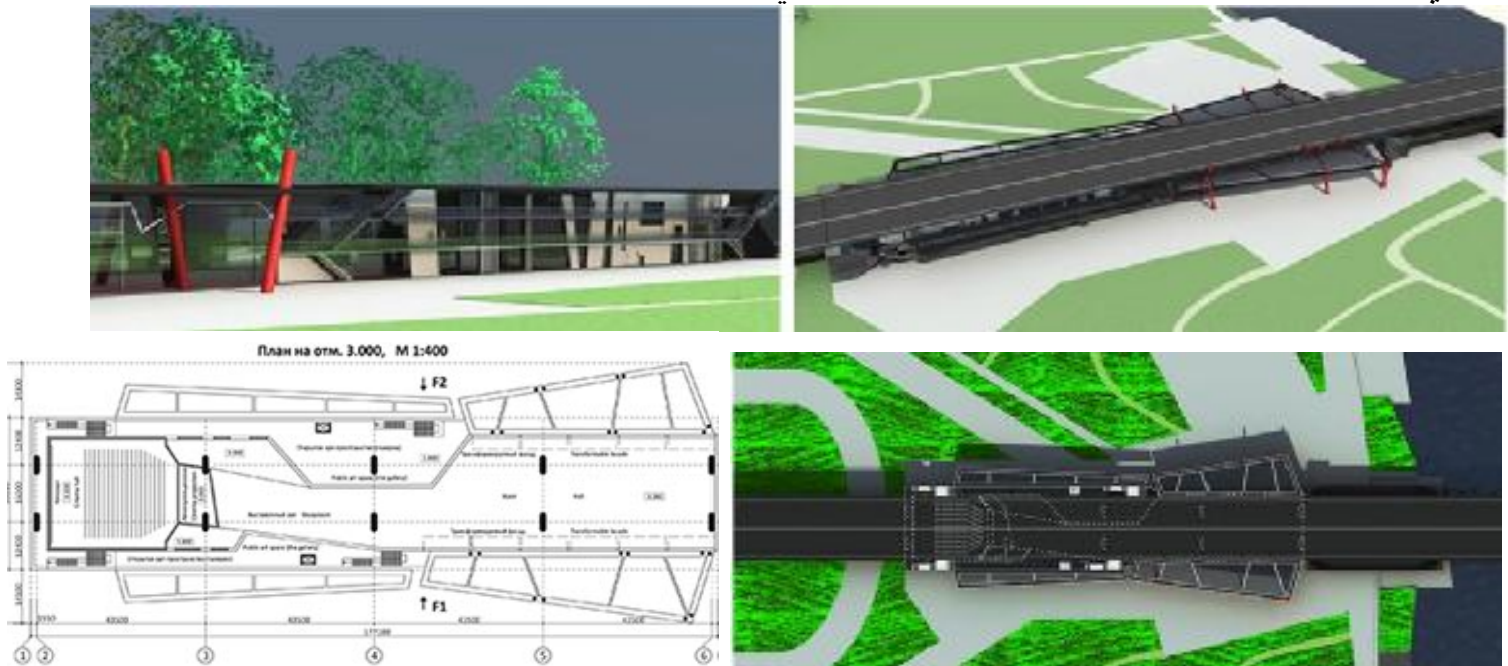

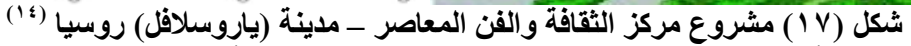

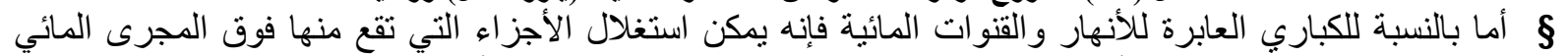

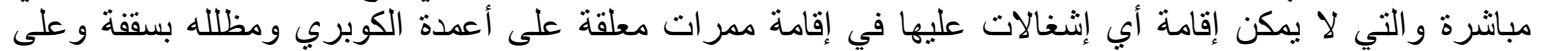

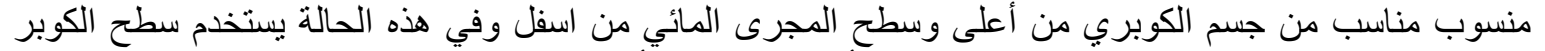

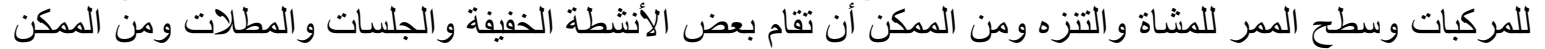

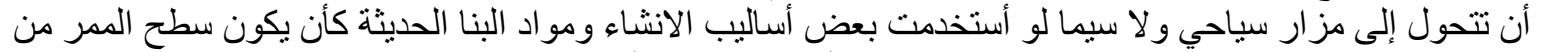

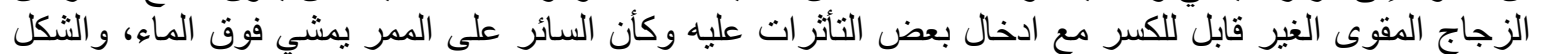

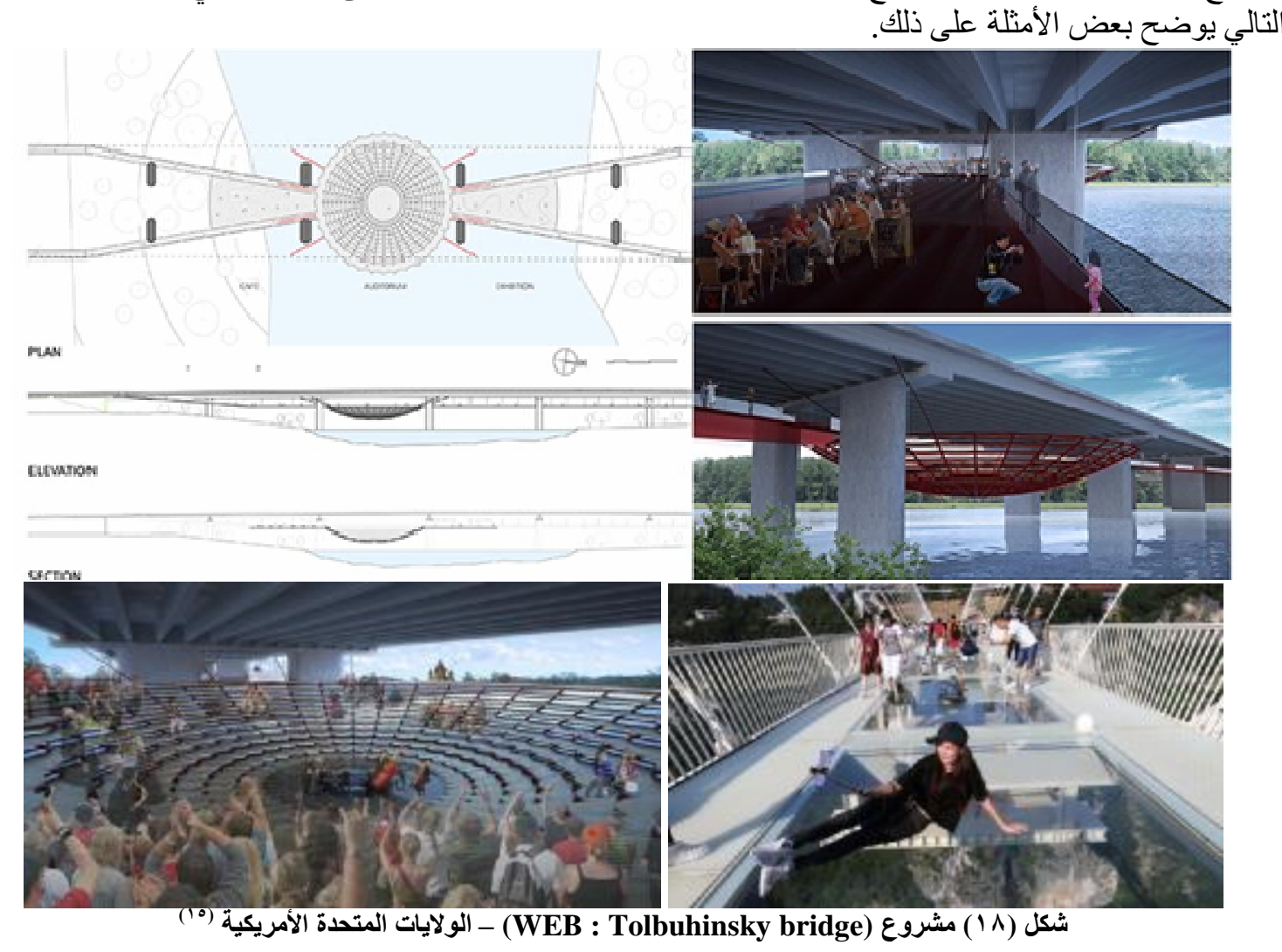


هـ الإستراتيجية المقترحة لاستغلال الأراضي أسفل الكباري.

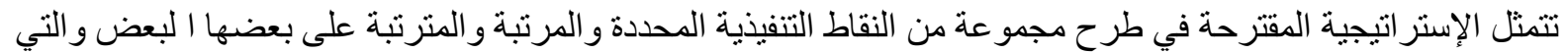

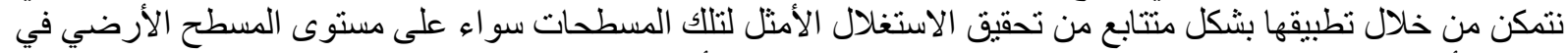
حد ذاته أو على مستوى المنطقة الو اقعة في إطار ها تلك المسطحات أسفل الكباري، وتتمثل هذه الإستر اتيجية فيما يلي:-

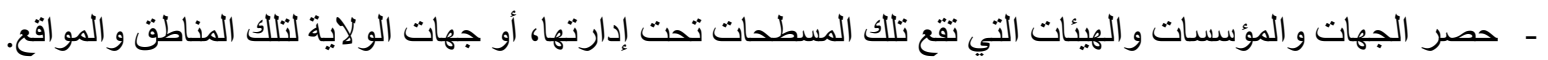

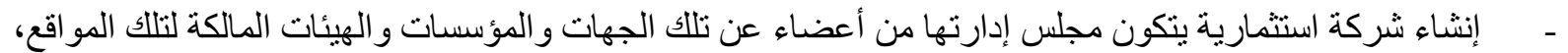

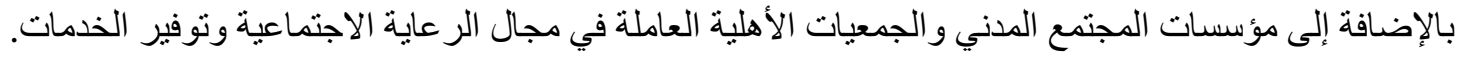

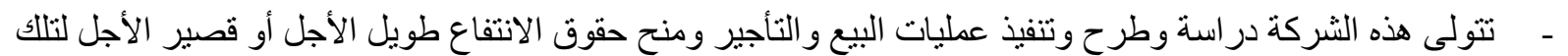

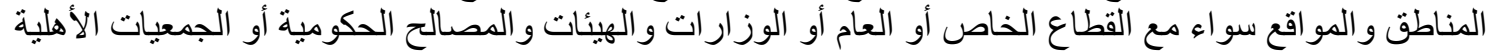

$$
\text { ومؤسسات المجتمع المدني. }
$$

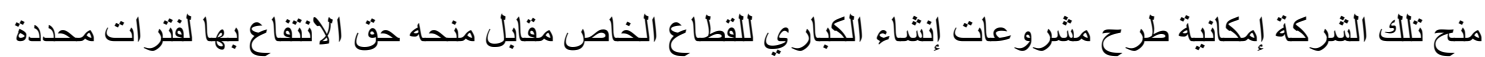

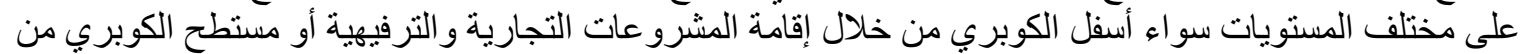

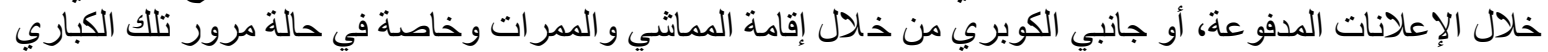

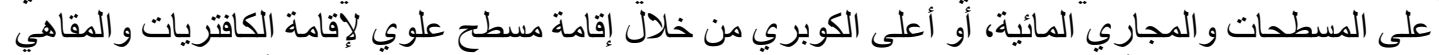

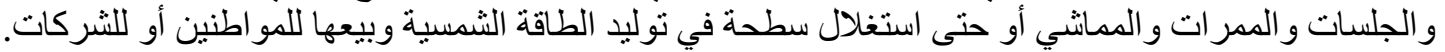
- أن تثكل للشركة ذر اع فنية واستشارية أو يكون لها حق الاستعانة بالجهات الفنية وبيوت الخبرة في مجال إنشاء وتنثييد الكباري.

العمل على إيجاد تصميمات متميزة و متفردة تعمل على الاستغلال المتعدد لتلك الكباري من خلال مسطحاها الأساسي و أسفلها و أعلاها. - ـ أن تكون للثركة إمك انية الاستغلال المباثر لتالك المو اقع أسفل الكباري أو أعلاها من خلال إقامة مشرو عات استثمارية تعمل على الاستغلال الأمثل لها.

أن تتلخل عناصر أخرى في تصميم الكباري وتحديد أنو اعها وطرق إنشائها تلتمثنل في تحقيق الاستفادة الاقتصادية

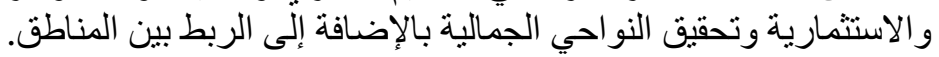

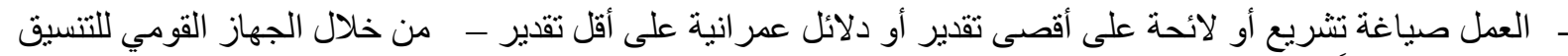

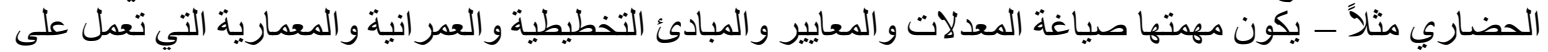

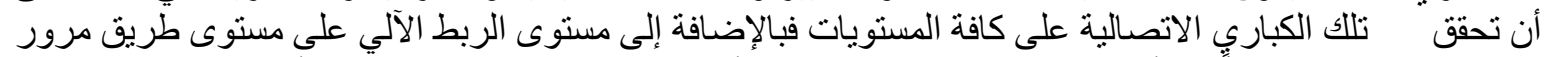

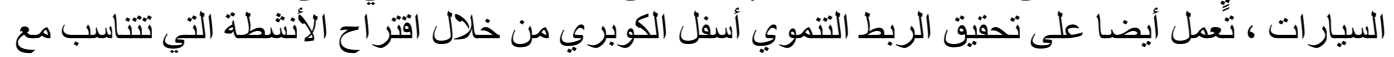

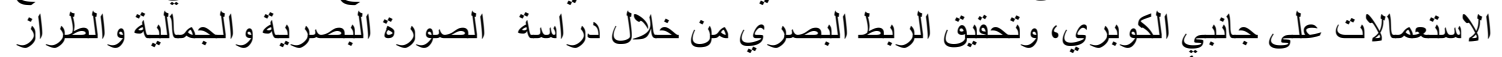

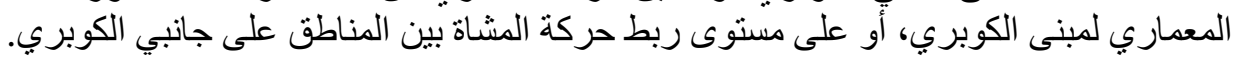

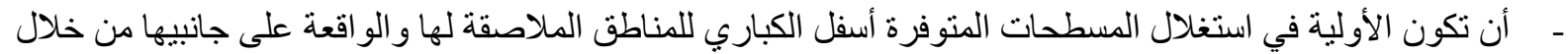

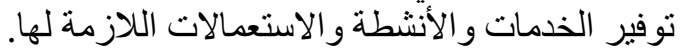

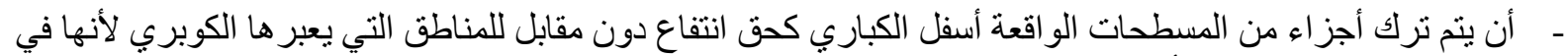

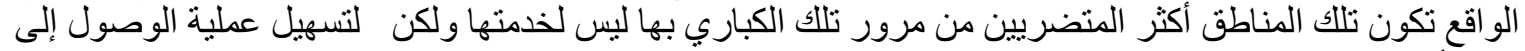
مناطق أخرى. - أن تكون الأولية في توفير فرص العمل للأيدي العاملة أو البطالة المتو اجدة في المناطق العمر انبة الملاصقة أو الواقعة على جانبي الكوبري.

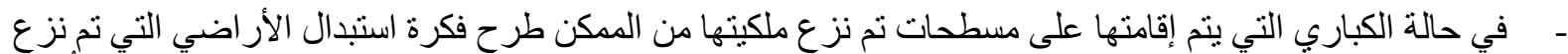

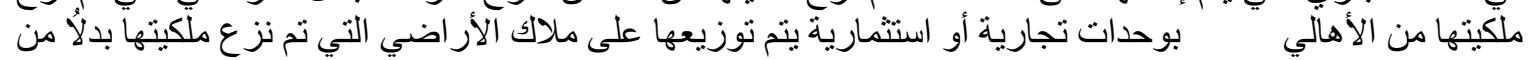
التعويض المادي في الحالات التي تسمح بذلكالك.

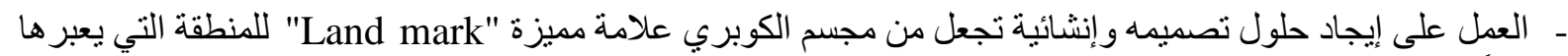

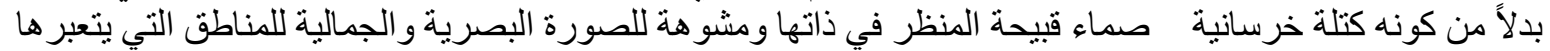

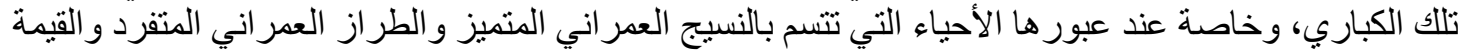

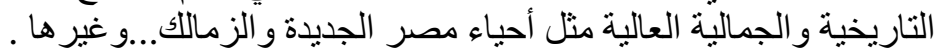


7ـ الانعكاسات العمرانية والاجتماعية لاستغلال الأراضي أسفل الكباري العلوية.

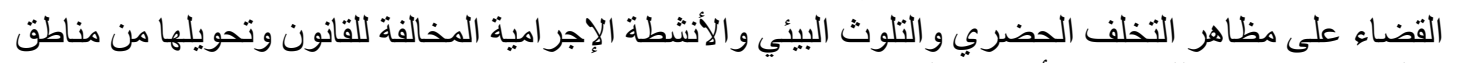

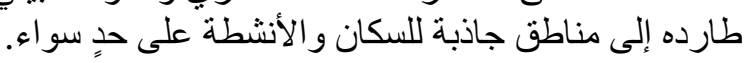

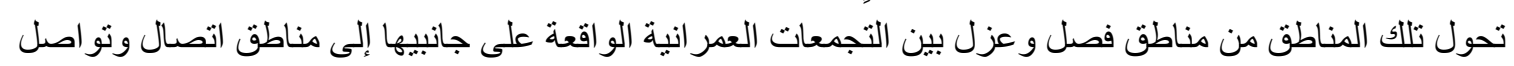
بين سكان المنطقتين المجاورنين.

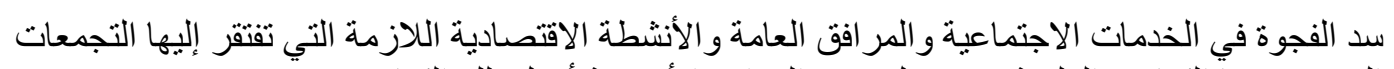

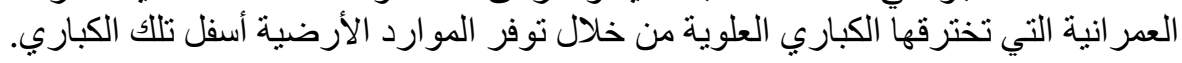

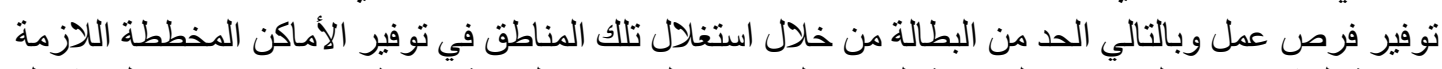

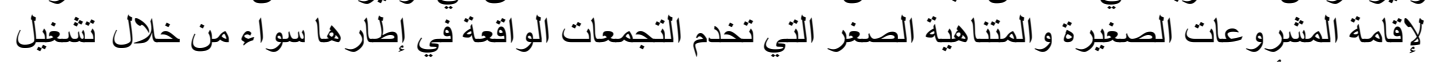

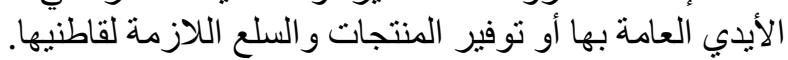

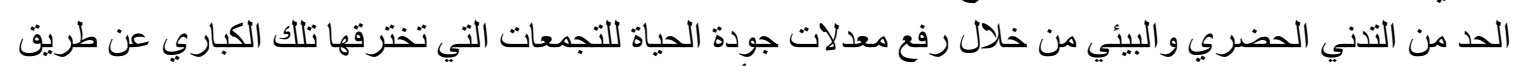

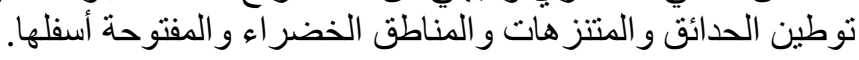

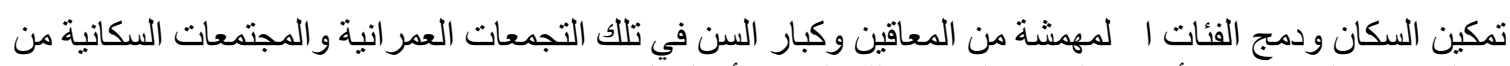

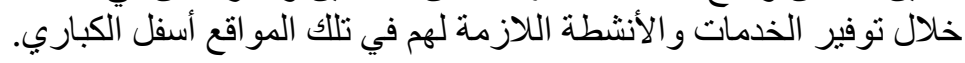

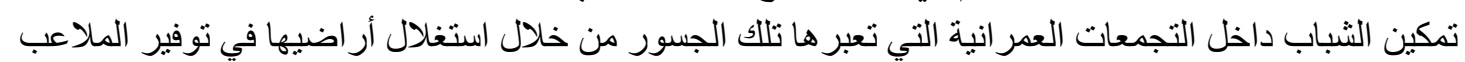

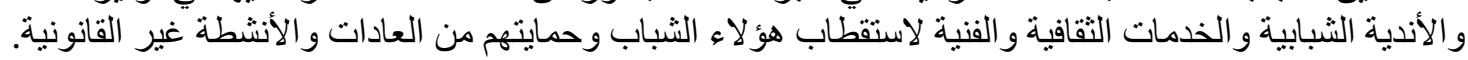

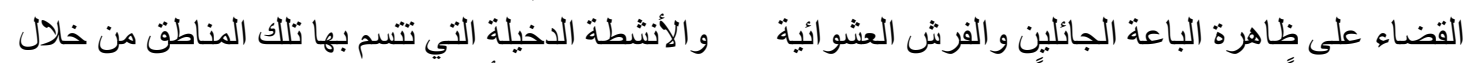

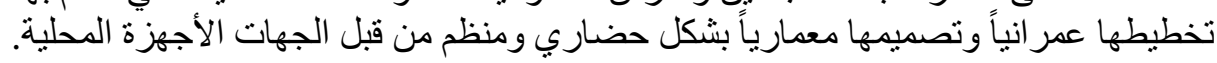

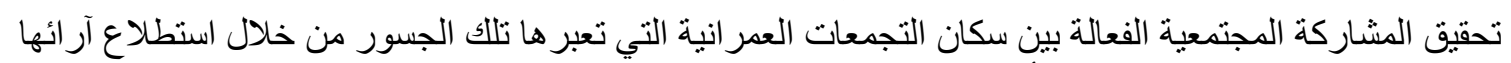

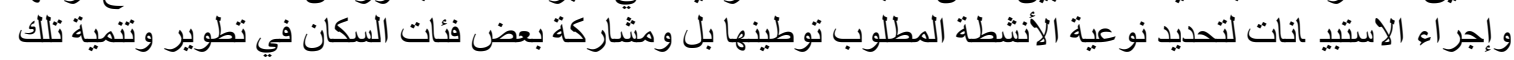

ضرورة حصر الكباري العلوية على مستوى الدولة من خلال الهيئات المسئولة والأجهزة المحلية، وحصر

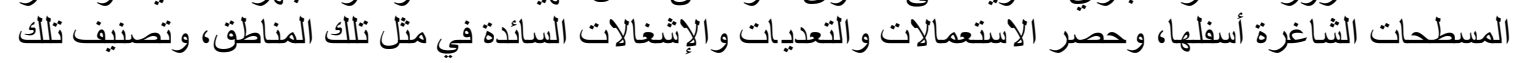

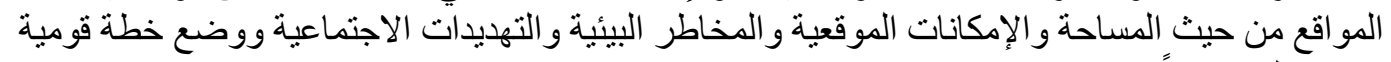
لتطو ير ها و استغخلالها تتموياً.

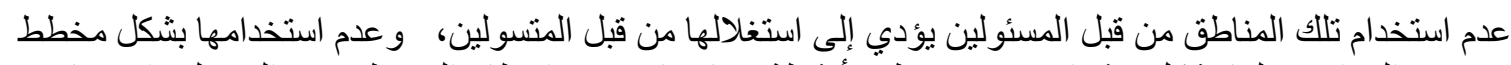

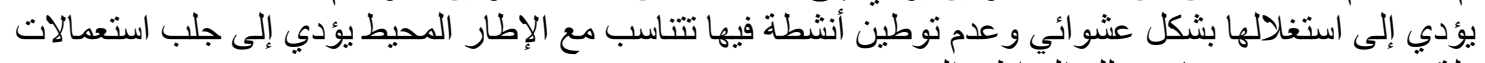

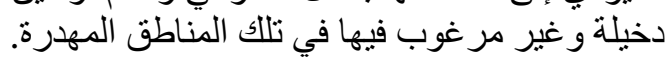

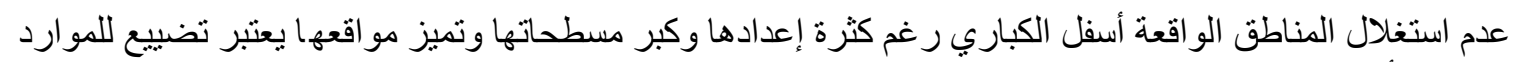

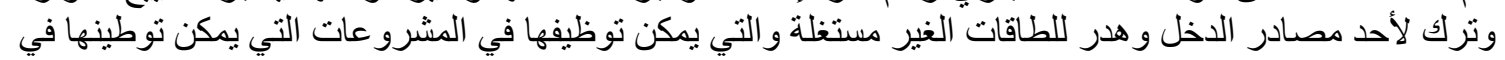
مثل تلاك المناطق.

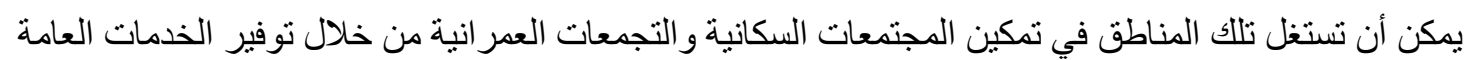

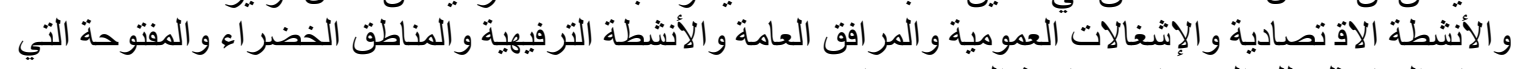

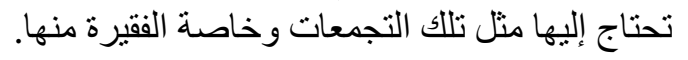

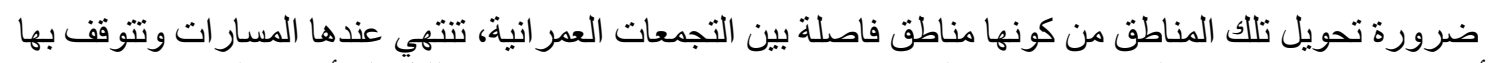

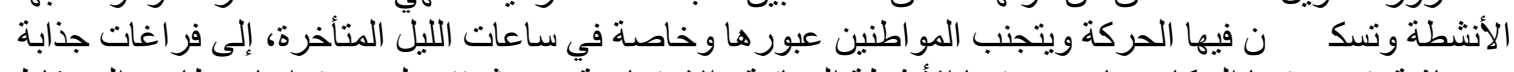

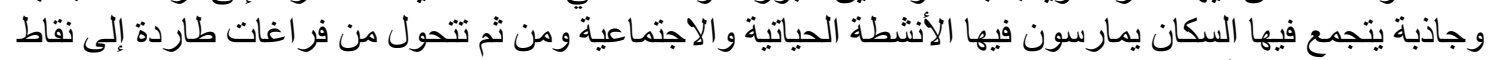

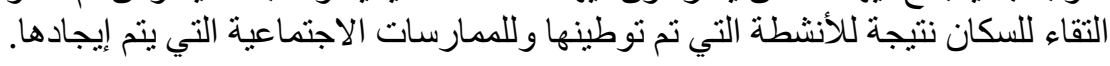

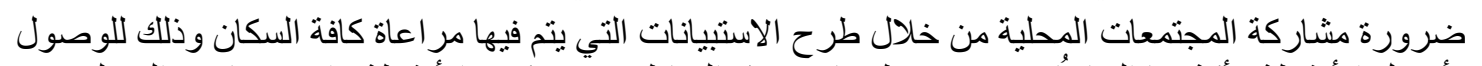

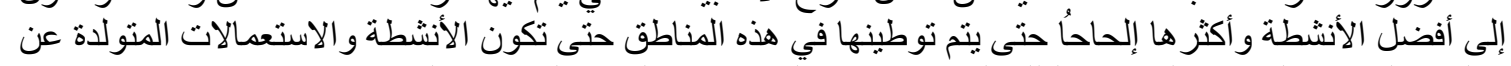

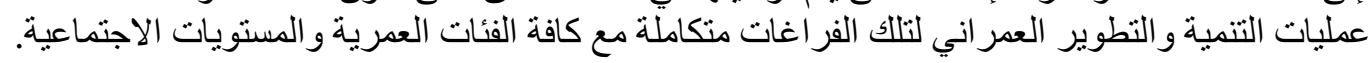

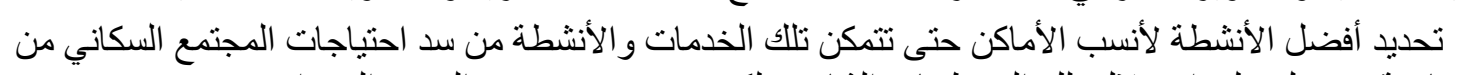

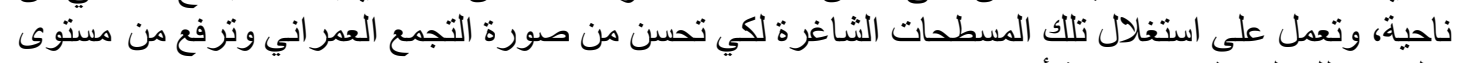
جودة الحياة بتلك المناطق من ناحية أخرى. 
ا. الجهاز المركزي للتعبئة العامة والاحصاء بجمهورية مصر العربية، يناير 9 أبـ، نشرة حصر الطرق والكباري

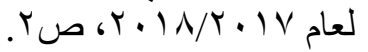

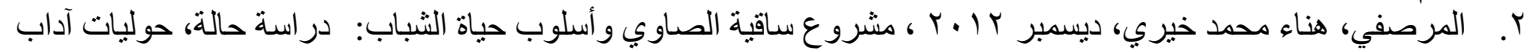

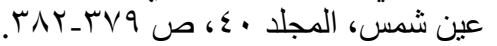

4. http://www.culturewheel.com/ar/page/about-sakia

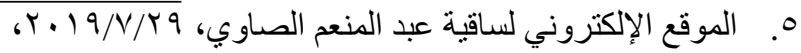

6. http://www.culturewheel.com/ar/page/what-we-offer

7. Oskar Amiri, Piotr Maćkiewicz, 30/6/2019, (http://socialfest.ru/w/project/under-thebridge- for-people/), Under the bridge - for people project, Poland.

8. Architonic web site, 2/7/2019, https://www.architonic.com/en/project/nl-architectsa8erna/5100103

9. Quora web site, 4/7/2019, https://www.quora.com/What-is-the-best-way-to-utilize-spaceunder-fly-overs

10. Trends in Japan web site, 4/7/2019, https://web-japan.org/trends/11 food/jfd170601.html

11. Hyperallergic web site, 5/7/2019, https://hyperallergic.com/276583/rethinking-lifebeneath-our-cities-concrete-overpasses/

12. Caracasshots web site,8/7/2019, http://caracasshots.blogspot.com/2012/07/books-lookgood.html

13. Recipes for Distraction web site, $1 / 8 / 2019$,

14. http://recipesfordistraction.blogspot.com/2014/11/quaipo-handicraft-shops-under-thebridge.html

15. Skyline Architects office, 2/7/2019, http://socialfest.ru/w/project/under-the-bridge-park/, UNDER the BRIDGE park project, Russia.

16. shaggytexas web site, $3 / 8 / 2019$, http://www.shaggytexas.com/board/showthread.php/143217-Dallas-Shaggy-Tear-DownI-345

17. Alexander Chuvilin, 19/7/2019,

18. http://socialfest.ru/w/project/\%d1\%86\%d0\%b5\%d0\%bd\%d1\%82\%d1\%80, Center for Contemporary Art, Russia>

19. Heeyun Bangm, 2/7/2019, http://socialfest.ru/w/project/web-tolbuhinsky-bridge/, Tolbuhinsky bridge, Sang-Uk Park, USA. 